\title{
Why Judges, Not Juries, Should Set Punitive Damages
}

Paul Mogin $\uparrow$

In March 1989, the Exxon Valdez ran aground and spilled millions of gallons of oil into Prince William Sound. The trial court phase of the private civil suit concerning that accident culminated in 1996 in a $\$ 5.057$ billion judgment against Exxon. ${ }^{1} \mathrm{Al}-$ most the entire judgment was based on a jury's award of $\$ 5$ billion in punitive damages ${ }^{2}$ - the largest monetary penalty ever imposed in an American court.

If Exxon had been convicted of a crime, a judge would have determined its sentence. ${ }^{3}$ If Exxon had been found liable for a civil penalty under the Clean Water Act, a judge would have set the amount of its penalty. ${ }^{4}$ Punitive damages "share key characteristics of criminal sanctions"5 and are also similar to civil statutory penalties. ${ }^{6}$ But because Exxon's penalty was in the form of

$\dagger$ Partner, Williams \& Connolly, Washington, D.C.

I In re Exxon Valdez, No A-89-0095-CV (D Alaska, Sept 24, 1996), appeal pending.

2 In re Exxon Valdez, No A-89-0095-CV, 1995 US Dist IEXIS 12952, *12 (D Alaska).

3 In criminal cases (other than capital cases) sentences are determined by judges in both federal court and the courts of all but eight states. By statute, defendants in six states have a right, in cases triable to a jury, to have a jury fix their punishment, within the limits established by statute. Ark Code Ann \& 5-4-103 (Michie 1993); Ky Rev Stat Ann $\S$ 532.055(2) (Baldwin 1990 \& Supp 1997); Miss Code §§ 97-3-67, 97-3-71 (1994) (granting this right only for crimes of rape and statutory rape); 57 Okla Stat Ann $\$ 353$ (West 1991); Tex Crim Proc Code Ann Art 37.07 \& 2(b)(2) (Vernon 1981 \& Supp 1997) (giving defendant right to choose judge or jury); Va Code $§ 19.2-295$ (1995 \& Supp 1997). In Tennessee, defendants have such a right in misdemeanor cases. Tenn Code Ann § 40-20-104 (Michie 1990). In Missouri, a trial judge can impose a sentence less than or equal to the sentence chosen by the jury. Mo Ann Stat § 557.036(3) (Vernon 1979 \& Supp 1997).

Pursuant to a court-approved settlement with the state and federal governments, Exxon had pled guilty in 1991 to four misdemeanors, paid a $\$ 25$ million fine (remitted from $\$ 150$ million because Exxon had spent $\$ 2.5$ billion in cleanup costs), and agreed to pay $\$ 900$ million in additional cleanup costs. Judge Endorses $\$ 1$ Billion Exxon Valdez Settlement, Wash Post A4 (Oct 9, 1991); Tom Kenworthy and Hal Bernton, $\$ 1$ Billion-Plus Accord Reached in Exxon Spill, Wash Post A6 (Oct 1, 1991).

- See 33 USC \& 1319(d) (1994); Tull v United States, 481 US 412, 426-27 (1987).

5 Landgraf v USI Film Products, 511 US 244, 281 (1994) (holding that the punitive damages provision of Section 102(b)(1) of the Civil Rights Act of 1991 cannot be applied to conduct that occurred before the law was enacted).

- Tull, 481 US at 422 n 7 . 
punitive damages, a jury determined how much Exxon should pay.

The Exxon Valdez litigation epitomizes a disparity in the allocation of penalty-setting power that exists both in federal court and in nearly all state courts. ${ }^{7}$ Noting this disparity, the Fourth Circuit recently adopted a new and more stringent standard for post-trial review of jury awards of punitive damages. ${ }^{8}$ It concluded that, to the extent that a punitive damages award rests on a policy judgment (as opposed to a determination of the facts), a trial judge deciding a motion for remittitur may independently assess how much the defendant should be punished. ${ }^{9}$

Similarly, bills concerning product liability cases introduced in Congress in recent years would have given both federal and state trial judges a greater role in awarding punitive damages. In general, the bills would cap punitive damages at the greater of $\$ 250,000$ or two times compensatory damages, and a jury's award exceeding the cap could stand only if the trial judge determined in a separate proceeding that the jury's award was warranted. ${ }^{10}$

This Article considers whether, as to cases brought in federal court, the courts can and should go further than either the Fourth Circuit or the recent bills, and squarely place all of the

7 Juries set punitive damages in the first instance in federal court and in the courts of nearly every state that permits the recovery of such damages. The exceptions are the Kansas courts and, in certain actions, the Connecticut courts. Kan Stat Ann \& 60-3701(a) (Supp 1992); Gen Stat Conn \$§ 31-290a(b), 35-53(b), 36a-618, 42-110g(a), 46a-98(d), 52240b (1997).

${ }^{8}$ Atlas Food Systems \& Services v Crane National Vendors, 99 F3d 587, 594-95 (4th Cir 1996).

9 The Fourth Circuit acknowledged that juries are well suited to determine facts relevant to the amount of punitive damages, but stressed that "other policy-related elements-e.g., the likelihood that an award will deter the defendant or others from engaging in similar conduct-are not factual questions and, therefore, are more appropriately decided by the trial judge." Id at 594. The Fourth Circuit concluded that "when reviewing the amount of a jury's punitive award under Federal Rule of Civil Procedure 59, the district court has a participatory decisionmaking role that it does not have when reviewing a jury's findings based solely on facts." Id. "While a district court must give due respect to a jury's comparative advantages in initially deciding upon the amount of punitive damages to award, the court may depart from that award to the extent that it concludes that its own comparative advantages warrant such a departure. ... The court's review of the amount of a punitive damage award should involve comparison of the court's independent judgment on the appropriate amount with the jury's award to determine whether the jury's award is so excessive as to work an injustice." Id at 595.

${ }^{10}$ See S 5, 105th Cong, 1st Sess $§ 108$ (Jan 21, 1997); S 648, 105th Cong, 1st Sess $\S 108$ (Jan 21, 1997). In March 1996, Congress passed a bill containing similar provisions, but President Clinton vetoed it. Common Sense Product Liability Reform Act of 1996, introduced as Common Sense Product Liability Reform Act of 1995, HR 956, 104th Cong, 2d Sess (Feb 15, 1995), in 141 Cong Rec H 1849 (Feb 15 1995). On May 6, 1996, the House failed to override the veto. 
power to decide the amount of punitive damages with trial judges. ${ }^{11}$ The Supreme Court has never decided whether the Seventh Amendment, which preserves the right to a jury trial in civil cases brought in federal court, ${ }^{12}$ confers a right to have punitive damages set by a jury. ${ }^{13}$ Three Justices recently implied that the Amendment confers no such right, observing, in Gasperini $v$ Center for Humanities, Inc, ${ }^{14}$ that "the level of punitive damages is not really a 'fact' 'tried' by the jury."

"In 1991, President Bush's Council on Competitiveness advocated shifting the power to assess punitive damages from juries to judges. See $A$ Report from the President's Council on Competitiveness, Agenda for Civil Justice Reform in America 22 (1991). A Senate committee has done likewise. See S 44, 98th Cong, 2d Sess § 12(c) (1984) (proposed law providing for judicial assessment of punitive damages in product liability cases in federal court), discussed in Product Liability Act, S Rep No 476, 98th Cong, 2d Sess 59 (1984) (committee report accompanying S 44). See also S 100, 99th Cong, 1st Sess § 12(c) (1985) (bill containing similar provision); HR 5214, 98th Cong, 2d Sess $\S 11(b)$, (c) (1984) (providing for judicial determination of both liability for, and amount of, punitive damages); $S$ 2631, 97th Cong, 2d Sess \$13(c) (1982) (same). Many commentators agree. See, for example, Lisa M. Sharkey, Comment, Judge or Jury: Who Should Assess Punitive Damages?, 64 U Cin L Rev 1089, 1128-29 (1996); David G. Owen, Comment, Civil Punishment and the Public Good, 56 S Cal L Rev 103, 120 (1992); Dorsey H. Ellis, Jr., Punitive Damages, Due Process, and the Jury, 40 Ala L Rev 975, 1005-07 (1989); Richard C. Ausness, Retribution and Deterrence: The Role of Punitive Damages in Products Liability Litigation, $74 \mathrm{Ky} \mathrm{L} \mathrm{J}$ 1, 124 (1985); James B. Sales and Kenneth B. Cole, Jr., Punitive Damages: A Relic That Has Outlived Its Origins, 37 Vand L Rev 1117, 1167-68 (1984); Jane Mallor and Barry Roberts, Punitive Damages: Toward a Principled Approach, 31 Hastings L J 639, 664 (1980). Judge Kozinski also has questioned the assignment to juries of the power to set punitive damages. See Alex Kozinski, The Case of Punitive Damages vs. Democracy, Ind Law 12 (Oct 30-Nov 12, 1996).

12 "In Suits at common law, where the value in controversy shall exceed twenty dollars, the right of trial by jury shall be preserved, and no fact tried by a jury, shall be otherwise re-examined in any Court of the United States, than according to the rules of the common law." US Const, Amend VII.

${ }^{13}$ Unlike nearly all of the other protections of the Bill of Rights, the guarantees of the Seventh Amendment have not been held to apply to the states through the Fourteenth Amendment. "The Seventh Amendment ... governs proceedings in federal court, but not in state court." Gasperini $v$ Center for Humanities, Inc, 116 S Ct 2211, 2222 (1996) (footnote omitted). See Walker $v$ Sauvinet, 92 US 90, 92 (1875) (Seventh Amendment is not a "privilege or immunity ... which the states are forbidden by the Fourteenth Amendment to abridge."). The Seventh Amendment governs the right to jury trial in diversity as well as federal question cases. Simler $v$ Conner, 372 US 221, 222 (1963).

" 116 S Ct 2211, 2235 (1996) (Scalia, joined by Rehnquist and Thomas, dissenting). Justice Scalia was quoting the Re-examination Clause of the Seventh Amendment, which provides that "no fact tried by a jury, shall be otherwise re-examined in any Court of the United States, than according to the rules of the common law." US Const, Amend VII. The issue in Gasperini, which involved an award of compensatory damages, was whether the Re-examination Clause precludes appellate review when a trial court denies a motion seeking a new trial because the jury's verdict was excessive. The Court held that the Reexamination Clause does not preclude such review. $116 \mathrm{~S} \mathrm{Ct}$ at 2223-24. Justice Scalia, joined by Chief Justice Rehnquist and Justice Thomas, would have held that the Reexamination Clause prohibits appellate review of awards of compensatory damages, but apparently would have reached a different conclusion as to punitive damages because the 
The Supreme Court's 1987 decision in Tull $v$ United States ${ }^{15}$ also indicates that the Seventh Amendment may not require jury assessment of the amount of punitive damages. Tull held that a citizen sued by the United States for a penalty under the Clean Water Act had a right to have a jury determine his liability for a penalty, but not its amount. The Court broadly stated that "[n]othing in the Amendment's language suggests that the right to a jury trial extends to the remedy phase of a civil trial, ${ }^{16}$ and that it had seen "no evidence that the Framers meant to extend the right to a jury to the remedy phase of a civil trial."17

It is time to recognize that, at least in federal court, asking juries to set punitive damages is neither constitutionally required nor sound policy. The responsibility to decide the amount of punitive damages, if the jury finds the defendant liable for such damages, should rest with the trial judge.

Part I of this Article discusses the origins of the Seventh Amendment and the basic principles reflected in the Supreme Court decisions interpreting it. Special attention is given to the Supreme Court decisions establishing that the Seventh Amend-

amount of punitive damages is not a "fact" tried by a jury. Id at 2231-36.

Whether state jury-trial guarantees entitle a party to have a jury set punitive damages is similarly an open question in most states. Forty-seven state constitutions protect the right to jury trial in civil cases in state court. See Ala Const, Art I, § 11; Alaska Const, Art I, § 16; Ariz Const, Art II, § 23; Ark Const, Art II, § 7; Cal Const, Art I, § 16; Conn Const, Art I, § 19; Del Const, Art 1, § 4; Fla Const, Art I, § 22; Ga Const, Art I, § 1, II 11; Hawaii Const, Art I, \& 13; Idaho Const, Art I, \& 7; Ill Const, Art I, § 13; Ind Const, Art I, § 20; Iowa Const, Art I, § 9; Kan Const, Bill of Rights § 5; Ky Const, Bill of Rights § 7; Me Const, Art I, § 20; Md Const, Declaration of Rights, Art 23; Mass Const, pt I, Art 15; Mich Const, Art I, § 14; Minn Const, Art I, § 4; Miss Const, Art III, § 31; Mo Const, Art 1, $\S 22(\mathrm{a})$; Mont Const, Art II, § 26; Neb Const, Art I, § 6; Nev Const, Art I, § 3; NH Const, pt I, Art 20; NJ Const, Art I, II 9; NM Const, Art II, § 12; NY Const, Art I, § 2; NC Const, Art I, § 25 (limiting preservation of civil jury trial to "all controversies at law respecting property"); ND Const, Art I, \& 13; Ohio Const, Art I, § 5; Okla Const, Art II, § 19; Or Const, Art VII, § 3; Pa Const, Art I, § 6; RI Const, Art I, § 15; SC Const, Art I, § 14; SD Const, Art VI, § 6; Tenn Const, Art I, § 6; Tex Const, Art I, § 15; Utah Const, Art I, § 10 (held to protect civil jury right in International Harvester Credit Corp $v$ Pioneer Tractor and Implement, Inc, 626 P2d 418, 421 (Utah 1981)); Vt Const, ch I, Art 12; Va Const, Art I, § 11; Wash Const, Art I, § 21; W Va Const, Art III, § 13; Wis Const, Art I, § 5. Compare Smith v Printup, $254 \mathrm{Kan} 315,866 \mathrm{P2d} 985,994$ (1993) (holding that there is no right to have a jury set punitive damages), with Zoppo $v$ Homestead Insurance Co, 71 Ohio St 3d'552, 644 NE2d 397, 401 (Ohio 1994), cert denied, 116 S Ct 56 (1995) (voiding statute that permitted court to set punitive damages), and Henderson By Hartsfield v Alabama Power Co, 627 S2d 878, 885-86, 893-94 (Ala 1993) (striking down legislative cap on punitive damages as violating the right to trial by jury).

${ }^{15} 481$ US 412, 426-27 (1987).

${ }^{16}$ Id at $426 \mathrm{n} 9$.

${ }^{17}$ Id. The Fourth Circuit relied upon Tull in its recent decision endorsing more stringent review of jury awards of punitive damages. Atlas, 99 F3d at 595. 
ment preserves only the substance of the right of trial by jury that was recognized by the English common law in the eighteenth century.

Part II examines certain Supreme Court decisions that some courts and commentators have read as establishing a Seventh Amendment right to a jury determination of the amount of punitive damages. This Part concludes that the decisions do not establish the existence of such a right.

Part III analyzes the Supreme Court's decision in Tull.

Part IV demonstrates that having juries fix punitive damages is not necessary to preserve the substance of the commonlaw right to trial by jury. Under the English common law, there was no right to a trial by jury on the issue of damages. In some cases damages were determined in a trial by jury before a judge, but often they were set by an inquest jury in a proceeding before a sheriff pursuant to a writ of inquiry. Such an inquest was intended to inform the conscience of the court, which could instead assess damages itself. Moreover, the common law developed for centuries before 1791, but punitive damages were not recognized until $1763 .{ }^{18}$ In one of the early cases allowing damages in excess of the plaintiff's injury, damages were decided by a jury pursuant to a writ of inquiry. ${ }^{19}$ Punitive damages today also differ significantly from punitive damages in eighteenth century England.

Part $\mathrm{V}$ argues that, as a matter of policy, the power to set punitive damages in federal court should rest with trial judges, subject to appellate review, rather than with juries. Judges are less susceptible to emotional factors, less likely to be unduly influenced by a defendant's wealth, more experienced in imposing punishment, and more knowledgeable of the punishment imposed in other cases.

Finally, Part VI shows that neither a new statute nor an amendment to the Federal Rules of Civil Procedure is necessary to permit federal trial judges to determine the amount of punitive damages.

\section{HISTORY OF THE SEVENTH AMENDMENT AND ITS INTERPRETATION}

The Constitution approved in September 1787 by the Constitutional Convention in Philadelphia guaranteed the right to a

${ }^{18}$ See Wilkes $v$ Wood, Lofft 1, 98 Eng Rep 489, $498-99$ (CP 1763); Huckle $v$ Money, 2 Wils KB 205, 95 Eng Rep 768, 769 (KB 1763).

${ }^{19}$ See Benson v Frederick, 3 Burr 1845, 97 Eng Rep 1130, 1130 (KB 1766). 
jury trial in criminal cases, ${ }^{20}$ but it said nothing of the right to a jury trial in civil cases. It also lacked a bill of rights. The proposed Constitution became the focus of a vigorous debate throughout the country, with the Anti-Federalists vociferously attacking it and the Federalists defending it. The AntiFederalists objected most strongly to the lack of a bill of rights, the Supreme Court's appellate jurisdiction as to law and fact, and the absence of a civil jury-trial guarantee. ${ }^{21}$

In several states, the Anti-Federalists succeeded in obtaining support for proposed amendments protecting the right to jury trial in civil cases. The Virginia Ratifying Convention urged the adoption of an amendment providing that, "in controversies respecting property, and in suits between man and man, the ancient trial by jury is one of the greatest securities to the rights of the people, and [is] to remain sacred and inviolable. ${ }^{222}$ New York's convention proposed essentially the same amendment. ${ }^{23}$ The Massachusetts and New Hampshire conventions proposed an amendment stating that "[i]n civil actions between Citizens of different States every issue of fact arising in Actions at common law shall be tried by a Jury, if the parties, or either of them, request it."24

In response, the Federalists denied that the Constitution was intended to limit jury trials in civil cases, ${ }^{25}$ and they promised to enact legislation to protect the right to a jury trial in such cases. ${ }^{26}$ The Anti-Federalists insisted, however, on a constitutional guarantee. ${ }^{27}$ Their efforts led to the inclusion in the Bill of Rights of what became the Seventh Amendment, guaranteeing a jury trial in suits at common law and restricting re-examination of jury verdicts:

In Suits at common law, where the value in controversy shall exceed twenty dollars, the right of trial by jury shall be pre-

${ }^{20}$ US Const, Art IV, § 2, cl 3.

${ }^{21}$ See Edith Guild Henderson, The Background of the Seventh Amendment, 80 Harv L Rev 289, 295 (1966).

2 Jonathan Elliot, 3 The Debates in the Several State Conventions, on the Adoption of the Federal Constitution 658 (2d ed 1836) ("Elliot's Debates").

${ }^{23} 1$ Elliot's Debates at 328-29.

${ }^{24}$ Ralph Ketcham, ed, The Anti-Federalist Papers and the Constitutional Convention Debates 219 (Mentor 1986); 1 Elliot's Debates at 326.

${ }^{25}$ See, for example, Federalist 83 (Hamilton), in Clinton Rossiter, ed, The Federalist Papers 495, 498-99 (Mentor 1961).

${ }^{25}$ See Charles W. Wolfram, The Constitutional History of the Seventh Amendment, 57 Minn L Rev 639, 666 (1973).

${ }^{27}$ See, for example, 3 Elliot's Debates at 579, 651-52. 
served, and no fact tried by a jury, shall be otherwise reexamined in any Court of the United States, than according to the rules of the common law. ${ }^{28}$

The Bill of Rights was approved by Congress in September $1789,{ }^{29}$ and obtained the required approval of three-fourths of the states in late $1791 .^{30}$

Although the general words of the Seventh Amendment were sufficient to secure agreement in 1791, their meaning has been sharply disputed many times in the two centuries since. ${ }^{31}$ The Supreme Court has interpreted the Seventh Amendment in dozens of decisions, not all of them consistent with each other. ${ }^{32}$

Despite the controversy and uncertainty that have surrounded the Seventh Amendment, several pertinent principles concerning its scope are reasonably well established. The Supreme Court has held that the "common law" referred to in the Seventh Amendment is the common law of England, ${ }^{33}$ though not all aspects of the English jury-trial system that existed in 1791

28 US Const, Amend VII.

2 I Stat 98 (1789).

${ }^{30}$ See Wolfram, 57 Minn L Rev at 730 (cited in note 26) (reviewing the constitutional history of the Seventh Amendment).

${ }^{31}$ The Seventh Amendment has generated extensive scholarly commentary. Some of the leading articles are Wolfram, 57 Minn L Rev 639 (cited in note 26); Martin H. Redish, Seventh Amendment Right to Jury Trial: A Study in the Irrationality of Rational Decision Making, $70 \mathrm{Nw}$ U L Rev 486 (1975) (arguing that the Supreme Court should take account of social conditions when interpreting the Seventh Amendment); Harold Chesnin and Geoffrey C. Hazard, Jr., Chancery Procedure and the Seventh Amendment: Jury Trial of Issues in Equity Cases Before 1791, 83 Yale L J 999 (1974) (showing that jury practice was in transition in England during the 1790s, and suggesting that Seventh Amendment interpretation is more complex than previously thought); Henderson, $80 \mathrm{Harv} L$ Rev 289 (cited in note 21) (arguing that the Seventh Amendment was not intended to codify existing jury practice because there was no consistent practice in 1791); and Austin Wakeman Scott, Trial by Jury and the Reform of Civil Procedure, 31 Harv L Rev 669 (1918) (discussing historical features of trial by jury and examining methods for controlling jury power).

${ }^{32}$ Compare, for example, Dimick v Schiedt, 293 US 474, 487 (1935) ("[H]ere, we are dealing with a constitutional provision which has in effect adopted the rules of the common law, in respect of trial by jury, as these rules existed in 1791."), with Gasperini $v$ Center for Humanities, Inc, 116 S Ct 2211, 2224 n 20 (1996) (noting that the meaning of the Seventh Amendment was not fixed as of 1791). See also notes 60, 75-76, and accompanying text.

${ }^{33}$ Markman $v$ Westview Instruments, Inc, 116 S Ct 1384, 1389 (1996); Baltimore \& Carolina Line, Inc $v$ Redman, 295 US 654, 657 (1935); Dimick, 293 US at 476-77; Thompson v Utah, 170 US 343, 350 (1898), overruled on other grounds by Collins v Youngblood, 497 US 37 (1989). See United States $v$ Wonson, 28 F Cases 745, 750 (Cir Ct D Mass 1812) (opinion by Story). Compare Markman, $116 \mathrm{~S}$ Ct at $1389 \mathrm{n} 3$ ("Our formulations of the historical test do not deal with the possibility of conflict between actual English common law practice and American assumptions about what that practice was, or between English and American practices at the relevant time.”). 
are preserved against change. ${ }^{34}$ As a result, opinions interpreting the Amendment have often included attempts to delve into the law of eighteenth century England. ${ }^{35}$ The Court has also held that the Jury Trial Clause and the Re-examination Clause are independent. ${ }^{36}$ Thus, even if a matter is not triable of right to a jury under the Jury Trial Clause, if it is so tried the Re-examination Clause limits post-trial and appellate review of the jury's verdict.

Although the Jury Trial Clause refers to "Suits at common law," it has been interpreted to guarantee a jury trial not only on causes of action that existed under the English common law, but also on many causes of action not recognized until long after 1791. In several cases, the Supreme Court has applied a twopronged test in deciding whether a party is entitled to a jury trial on a cause of action unknown to the English common law: the first prong compares the new cause of action with actions brought in eighteenth century England and asks whether similar causes of action were tried to a jury; the second prong examines the nature of the remedy sought. ${ }^{37}$

It is well-settled that, even if a given cause of action triggers a right to a jury trial, that right does not necessarily encompass all issues relating to that cause of action. ${ }^{38}$ In its most recent discussion of this aspect of Seventh Amendment doctrine, the Supreme Court explained in Markman $v$ Westview Instruments,

${ }^{34}$ See notes $45-68,76-77$, and accompanying text.

${ }^{35}$ See, for example, Markman, $116 \mathrm{~S}$ Ct at 1389-93.

${ }^{36}$ Parsons $v$ Bedford, 28 US (3 Pet) 433, 447 (1830).

${ }^{3}$ See Wooddell $v$ International Brotherhood of Electrical Workers, 502 US 93, 97-98 (1991); Chauffeurs, Teamsters and Helpers Local $391 v$ Terry, 494 US 558, 565 (1990) (plurality opinion); Granfinanciera, SA v Nordberg, 492 US 33, 42 (1989); Tull, 481 US at 41718. In its recent decision in Markman, where it was undisputed that the cause of action at issue triggered a right to jury trial on some issues, the Court applied the first prong of this test but not the second. $116 \mathrm{~S} \mathrm{Ct}$ at 1389-92. Earlier cases had treated the second prong as more important. See Terry, 494 US at 565 (plurality opinion); Granfinanciera, 492 US at 42; Tull, 481 US at 421. See also Curtis v Loether, 415 US 189, 194 (1974) (implying that "the relief sought here" prong is "more important" than analogous common law actions).

At least two cases applying the two-pronged test treated the presence of a claim for money damages as a factor strongly indicating that a particular cause of action triggered a right to a jury trial. See Terry, 494 US at 570; Curtis, 415 US at 196-97.

In dicta in a 1970 decision, the Court identified a third factor bearing on whether an issue is triable as of right to a jury: "the practical abilities and limitations of juries." Ross $v$ Bernhard, 396 US 531, 538 n 10 (1970). Most of the Court's Seventh Amendment decisions since Ross have ignored this factor. See, for example, Terry, 494 US at 565 (using twoprong test); Granfinanciera, 492 US at 42 (same). Part of the Markman opinion can be read as reviving it as a significant consideration when history does not supply a clear answer. $116 \mathrm{~S} \mathrm{Ct}$ at 1395.

${ }^{3}$ Markman, 116 S Ct at 1389-90; Tull, 481 US at 427. 
Inc ${ }^{39}$ that, "[i]f the action in question belongs in the law category, we then ask whether the particular trial decision must fall to the jury in order to preserve the substance of the common law right as it existed in $1791 .{ }^{n 0}$ For example, even if a statutory cause of action triggers the right to a jury trial under the Seventh Amendment, a discretionary award of attorney's fees under the statute may be determined by the trial court, not by a jury. ${ }^{41}$

The statement from Markman just quoted also embodies another established-but far from precise-principle of Seventh Amendment jurisprudence: the principle that the Amendment preserves only "the substance of the common law right" of trial by jury. ${ }^{42}$ The Supreme Court has declared that "the Amendment was designed to preserve the basic institution of jury trial in only its most fundamental elements, ${ }^{\text {s/3 }}$ and that "[o]nly those incidents which are regarded as fundamental, as inherent in and of the essence of the system of trial by jury, are placed beyond the reach of the legislature. ${ }^{.44}$

A series of nineteenth century Supreme Court decisions applying this fundamental-elements principle approved the directed verdict without pointing to any clear precedent for it in eighteenth century English law. ${ }^{45}$ Similarly, early in this century the Court held that the Seventh Amendment does not prohibit summary judgment, a procedural device that was unknown in England in $1791 .^{46}$

The fundamental-elements principle also was reflected in the Court's 1897 decision in Walker $v$ New Mexico \& Pacific Railroad $\mathrm{Co}^{47}$ where a jury's answers to special interrogatories were inconsistent with its general verdict. The issue was whether the trial court could enter judgment based on the answers to the special

116 S Ct 1384 (1996).

40 Id at 1389.

${ }^{41}$ See, for example, Columbus Mills, Inc $v$ Freeland, 918 F2d 1575, 1578 (11th Cir 1990); Pan Am World Airways, Inc v Ramos, 357 F2d 341, 342 (1st Cir 1966); Swofford v B \& W, Inc, 336 F2d 406, 413 (5th Cir 1964).

${ }^{42}$ Markman, 116 S Ct at 1389; Colgrove v Battin, 413 US 149, 156-57 (1973); Baltimore \& Carolina Line, Inc v Redman, 295 US 654, 657 (1935). See Capital Traction Co v Hof, 174 US 1, 23 (1899) ('It is not 'trial by jury,' but 'the right of trial by jury,' which the Amendment declares 'shall be preserved.").

${ }^{4}$ Galloway $v$ United States, 319 US 372, 392 (1943).

4 Tull, 481 US at 426, quoting Colgrove, 413 US at $156 \mathrm{n} 11$ (quoting Scott, 31 Harv L Rev at 671 (cited in note 31)); Markman, $116 \mathrm{~S} \mathrm{Ct}$ at 1389.

${ }^{45}$ See Baylis v Travellers' Insurance Co, 113 US 316, 320-21 (1885); Oscanyan v Arms Co, 103 US 261, 266-67 (1880); Pleasants $v$ Fant, 89 US (22 Wall) 116, 120-21 (1874); Parks $v$ Ross, 52 US (11 How) 362, 372-73 (1850).

${ }^{46}$ Fidelity \& Deposit Co $v$ United States, 187 US 315, 319-21 (1902).

${ }^{47} 165$ US 593, 594-95 (1897). 
interrogatories or could only grant a new trial. The Supreme Court did not cite any precedent in the English common law for entering a judgment contrary to the jury's general verdict. ${ }^{48} \mathrm{But}$ it held that the Seventh Amendment posed no obstacle to entry of such a judgment, because the purpose of the Amendment "is not to preserve mere matters of form and procedure but substance of right. ${ }^{349}$

Numerous decisions in this century reflect the continuing importance of the fundamental-elements principle. In 1920, the Supreme Court held in Ex parte Peterson ${ }^{50}$ that the Seventh Amendment was not violated by the appointment of an auditor to make a preliminary investigation, hear witnesses, examine financial records, and prepare a report to be admitted at trial as prima facie evidence. The Court acknowledged that "there did not exist in England, or so far as appears in any of the colonies, any officer, permanent or temporary, who, in connection with trials by jury, exercised the powers of an auditor above described. ${ }^{.51}$ The Court nonetheless found no constitutional violation, because "[n]ew devices may be used to adapt the ancient institution [of jury trial] to present needs and to make of it an efficient instrument in the administration of justice."\%2

In 1931, the Court held in Gasoline Products Co $v$ Champlin Refining $\mathrm{Co}^{53}$ that when a new trial is granted because of an error relating to one issue, the retrial may be limited to that issue, provided that "the issue to be retried is so distinct and separable from the others that a trial of it alone may be had without injustice." The Court so held despite the settled rule of the English common law that a retrial had to be of the entire case. ${ }^{54}$

In the 1943 case Galloway $v$ United States, ${ }^{55}$ Justice Black, joined in dissent by Justices Douglas and Murphy, attacked as violative of the Seventh Amendment the expanded use of the directed verdict that had been approved in a series of Supreme Court decisions between 1871 and 1929. In response, a six-Justice majority emphasized that the Constitution preserved only the most fundamental elements of the English jury-trial system:

\footnotetext{
${ }^{48}$ Id at 596-97.

19 Id at 596.

so 253 US 300, 310 (1920).

${ }^{51} \mathrm{Id}$ at 307-08.

${ }^{52}$ Id at 309-10.

${ }^{53} 283$ US 494, 500 (1931).

${ }^{54}$ See id at 497 .

${ }^{55} 319$ US 372, 404-05 (1943).
} 
The Amendment did not bind the federal courts to the exact procedural incidents or details of jury trial according to the common law in 1791, any more than it tied them to the common law system of pleading or the specific rules of evidence then prevailing. Nor were "the rules of the common law" then prevalent, including those relating to the procedure by which the judge regulated the jury's role on questions of fact, crystallized in a fixed and immutable system. On the contrary, they were constantly changing and developing during the late eighteenth and early nineteenth centuries. In 1791 this process already had resulted in widely divergent common-law rules on procedural matters among the states, and between them and England. And none of the contemporaneous rules regarding judicial control of the evidence going to juries or its sufficiency to support a verdict had reached any precise, much less final, form. In addition, the passage of time has obscured much of the procedure which then may have had more or less definite form, even for historical purposes.

-..

[T]he Amendment was designed to preserve the basic institution of jury trial in only its most fundamental elements, not the great mass of procedural forms and details, varying even then so widely among common-law jurisdictions. ${ }^{56}$

In its 1973 decision in Colgrove $v^{\circ}$ Battin, ${ }^{57}$ a sharply divided Court relied upon the fundamental-elements doctrine in holding that the "jury trial," as guaranteed by the Seventh Amendment, may be a trial before a jury of only six persons. ${ }^{58}$ The Court so held despite the tradition of twelve-person juries dating back at least to the fourteenth century, ${ }^{59}$ and despite the fact that many of the Court's own decisions had assumed that the Seventh Amendment requires a twelve-person jury. ${ }^{60}$ In an opinion by

${ }^{56}$ Id at 390-92 (footnotes omitted).

${ }^{67} 413$ US 149, 157, 160 (1973).

${ }^{\text {ss }}$ Compare Richard Arnold, Trial by Jury: The Constitutional Right to a Jury of Twelve in Civil Trials, 22 Hofstra L Rev 1 (1993) (criticizing Colgrove). 8.

${ }^{59}$ See Colgrove, 413 US at 176-77 (Marshall dissenting); Arnold, 22 Hofstra L Rev at

${ }^{\infty}$ See Slocum v New York Life Insurance Co, 228 US 364, 397 (1913); Maxwell v Dow, 176 US 581, 586 (1900) (criminal case noting that Seventh Amendment right "implies that there shall be an unanimous verdict of twelve jurors"); Capital Traction Co, 174 US at 13. Several other cases assume twelve-person juries, without discussing the Seventh Amendment. See Crowell v Benson, 285 US 22, 61 (1932); Herron v Southern Pacific Co, 283 US 91, 95 (1931); Railroad Co v Stout, 84 US (17 Wall) 657, 664 (1873). 
Justice Brennan, the Court explained that the divergence of state practices in 1791 had meant that the civil jury-trial provision of the Bill of Rights "would necessarily have to be general," and that in fact "the right was limited in general words to 'suits at common law." The Court could "only conclude .. . that by referring to the 'common law,' the Framers of the Seventh Amendment were concerned with preserving the right of trial by jury in civil cases where it existed at common law, rather than the various incidents of trial by jury. "62 The Court framed the question as "whether a jury of 12 is of the substance of the common-law right of trial by jury,"

In its 1979 decision in Parklane Hosiery Co $v$ Shore ${ }^{65}$ the Court again relied upon the fundamental-elements principle. The Securities and Exchange Commission ("SEC") had brought an equitable action in which it had secured a declaratory judgment against a corporation for issuing a false and misleading proxy statement. ${ }^{66}$ The Court held that the Seventh Amendment posed no obstacle to applying the doctrine of collateral estoppel against the corporation in a subsequent legal action by a class of stockholders, thus precluding the corporation from denying that the proxy statement was false and misleading. ${ }^{67}$ The Court so ruled even though at common law mutuality of parties was required before a party could be bound by a prior judgment, and the stockholders had not been parties to the SEC action. ${ }^{68}$

In its 1996 decision in Markman, the Court held that the Seventh Amendment right to a jury trial, though applicable to patent-infringement actions, does not confer a right to have a patent construed by a jury. ${ }^{69}$ The critical question, the Court said, was "whether the particular trial decision must fall to the jury in order to preserve the substance of the common-law right as it existed in 1791."70 To answer the question, the Court explained, "the sounder course, when available, is to classify a mongrel practice . . . by using the historical method, much as we do in charac-

\footnotetext{
${ }^{61}$ Colgrove, 413 US at 155.

${ }^{62}$ Id at 155-56 (footnotes omitted).

$\approx$ Id at 157 .

at Id.

65 439 US 322 (1979).

${ }^{66}$ Id at 324-25.

${ }^{67}$ Id at 337.

${ }^{68}$ See id at 335-37.

$116 \mathrm{~S}$ Ct at 1389, 1396.

${ }^{70}$ Id at 1389.
} 
terizing the suits and actions within which they arise. ${ }^{771}$ If an "exact antecedent" is lacking, "the best hope lies in comparing the modern practice to earlier ones whose allocation to court or jury we do know, ... seeking the best analogy we can between an old and the new." ${ }^{\prime 2}$

Gasperini, the Court's most recent Seventh Amendment decision, is also instructive, although it involved the Reexamination Clause rather than the Jury Trial Clause. ${ }^{73}$ At issue was the permissibility of appellate review of the denial of a motion to set aside a jury verdict as excessive. ${ }^{74}$ In several opinions from the late nineteenth and early twentieth centuries, the Court had interpreted the Seventh Amendment to bar such review. ${ }^{75}$ In Gasperini, however, the Court held such review to be "reconcilable with the Seventh Amendment as a control necessary and proper to the fair administration of justice. ${ }^{76}$ The Court cited no precedent for the practice in eighteenth century English law. Instead, the Court indicated that the meaning of the Seventh Amendment was not frozen in 1791:

If the meaning of the Seventh Amendment were fixed at 1791, our civil juries would remain, as they unquestionably were at common law, 'twelve good men and true' ... . But see Colgrove $v$. Battin (six-member jury for civil trial satisfies Seventh Amendment's guarantee). Procedures we have regarded as compatible with the Seventh Amendment, although not in conformity with practice at common law when the Amendment was adopted, include new trials restricted to the determination of damages, and Federal Rule of Civil Procedure 50(b)'s motion for judgment as a matter of law. ${ }^{77}$

"Id at 1390.

72 Id (citations omitted).

${ }^{73}$ See 116 S Ct at 2222.

"Id at 2216-17. The verdict in Gasperini was for compensatory damages only.

${ }^{75}$ See, for example, Lincoln $v$ Power, 151 US 436, 437-38 (1894); Railroad Co v Fraloff, 100 US 24, 31-32 (1879).

${ }^{76} 116 \mathrm{~S} \mathrm{Ct}$ at 2223.

$\pi$ Id at 2224 n 20 (citations omitted). See also id at 2225-30 (Stevens dissenting) (disagreeing with the majority on another issue, but agreeing that the Seventh Amendment did not bar appellate review and stating that "[t]here is nothing in its history or language to suggest that the Amendment had any purpose but to preserve the essentials of the jury trial as it was known to the common law before the adoption of the Constitution," quoting Dimick, 293 US at 490 (Stone dissenting)). "Judgment as a matter of law" is the term added to FRCP 50 in 1991, replacing the terms "directed verdict" and "judgment notwithstanding the verdict" in federal practice. 28 USCA Rule 50 (1992 \& Supp 1997) (Advisory Committee notes). 
The principle that the Seventh Amendment preserves only the most fundamental incidents of the English jury-trial system has greatly restricted the reach of the Amendment. The impact of the fundamental-elements principle can be seen today in matters as basic as the number of jurors in the jury box; motions made before, during, and after trial; and the scope of appellate review.

\section{SUPREME COURT CASES PURPORTEDLY ESTABLISHING THE RIGHT TO HAVE A JURY SET PUNITIVE DAMAGES}

Some courts and commentators have suggested that certain decisions of the Supreme Court involving awards of damages establish that the Seventh Amendment right to jury trial extends to determining the amount of punitive damages. This Part shows why those cases do not resolve this issue.

\section{A. Barry $v$ Edmunds}

The Supreme Court's 1886 decision in Barry $v$ Edmunds ${ }^{78}$ has been cited as authority that the Seventh Amendment confers a right to have a jury set punitive damages. ${ }^{79}$ The Court held that an action for trespass should not have been dismissed by the trial court for failure to satisfy the federal amount-in-controversy requirement, which at that time was $\$ 500{ }^{80}$ The trial court had explained that "if the jury should render a verdict for $(\$ 500)$ five hundred dollars damages such verdict would be excessive, and the court would feel compelled to set it aside. ${ }^{\$ 81}$ The Supreme Court concluded that, to the contrary, a jury could award more than $\$ 500$, because the value of the horse forcibly taken from the plaintiff by the defendant (\$100) "would not necessarily cover [the plaintiff's] actual, direct, and immediate pecuniary loss, ${ }^{, 82}$ and because the jury could award punitive damages. ${ }^{83}$

Of particular pertinence is the following passage in the $\mathrm{Su}-$ preme Court's opinion:

There was clear error in the Circuit Court in its ruling, as matter of law, that there could be no lawful recovery ... of an amount equal to that which is necessary to support the

${ }^{78} 116$ US 550 (1886).

${ }^{79}$ See, for example, Henderson By Hartsfield v Alabama Power Co, 627 S2d 878, 88891 (Ala 1993).

${ }^{80}$ See Barry, 116 US at 565.

${ }^{31}$ Id at 558.

${ }^{82}$ Id at 562.

${ }^{83}$ Id. 
jurisdiction of the court. The same error was repeated in acting upon the statement, that a verdict, if rendered for that amount, would be excessive and set aside for that reason-a statement which could not, at any rate, be judicially made before such a verdict was in fact rendered. It adds, indeed, to the principal error, if any distinction can be made, that which consists in encroaching upon the province of the jury. ... [I]n such cases as the present, and other actions for torts where no precise rule of law fixes the recoverable damages, it is the peculiar function of the jury to determine the amount by their verdict. ... . [A] verdict will not be set aside in a case of tort for excessive damages "unless the court can clearly see that the jury have committed some very gross and palpable error, or have acted under some improper bias, influence or prejudice, or have totally mistaken the rules of law by which the damages are to be regulated"-that is, "unless the verdict is so excessive or outrageous," with reference to all the circumstances of the case, "as to demonstrate that the jury have acted against the rules of law, or have suffered their passions, their prejudices, or their perverse disregard of justice to mislead them." In no case is it permissible for the court to substitute itself for the jury, and compel a compliance on the part of the latter with its own view of the facts in evidence, as the standard and measure of that justice, which the jury itself is the appointed constitutional tribunal to award..$^{84}$

It is clear from the parts of the opinion immediately preceding ${ }^{85}$ and following this passage ${ }^{86}$ that the "damages" referred to included punitive as well as compensatory damages. Therefore, the Court's statement that "the jury itself is the appointed constitutional tribunal to award" damages ${ }^{87}$ could be read to mean that the Jury Trial Clause entitles a party to have a jury determine the amount of punitive damages.

34 Id at 565 (latter emphasis added), quoting Whipple $v$ Cumberland Manufacturing Co, 29 F Cases 934, 937-38, 2 Story 661, 670 (Cir Ct D Me 1843).

${ }^{8}$ Barry, 116 US at 562 ("It is equally clear ... that the plaintiff is not limited in his recovery to the mere value of the property taken," and may "be entitled to exemplary damages.").

${ }^{\circ}$ Id at 566 ("The dignity and value of the rights assailed, and the power and authority of the source from which the assault proceeds, are elements to be considered in the computation of damages, not only compensation for the direct loss inflicted, but a remedy and prevention for the greater wrong and injury involved in the apprehension of its repetition.").

${ }^{87}$ Id at 565. 
But, considered in its entirety, Barry does not so hold. Whether compensatory damages or punitive damages were to be determined by a jury if the case proceeded to trial was not at issue; the trial court had explicitly assumed that damages would be for the jury to assess if the case were tried. ${ }^{88}$ The trial court had nevertheless dismissed the action because it had concluded that any jury verdict of more than $\$ 500$ would have been excessive. ${ }^{89}$ The Court's statement that "the jury itself is the appointed constitutional tribunal to award" damages followed a discussion that focused on the limitations of a court's power to set aside as excessive a jury's verdict in a tort action. ${ }^{90}$ The statement thus appears to have been made with reference to the Re-examination Clause rather than the Jury Trial Clause. The Court also spoke generally of damages in tort, and did not specifically address punitive damages. ${ }^{91}$

\section{B. Curtis v Loether}

Eighty-eight years after Barry, the Court addressed the right to a jury trial in another case involving a prayer for punitive damages. But, again, it did not hold that there was a right to have the jury set those damages.

In Curtis $v$ Loether, ${ }^{92}$ an African-American woman alleged that two white men had refused to rent her an apartment because of her race, in violation of Title VIII of the Civil Rights Act of $1968 .^{93}$ Her complaint sought injunctive relief and punitive

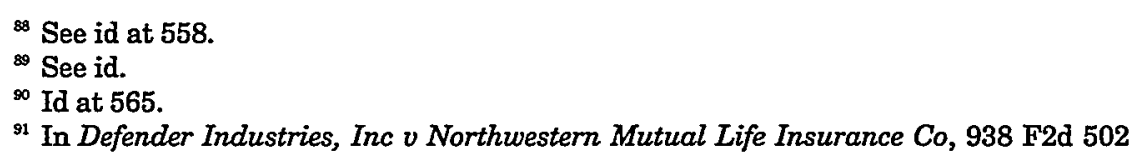
(4th Cir 1991) (en banc), the Fourth Circuit cited Kennon v Gilmer, 131 US 22 (1889), to support its conclusion that the Seventh Amendment right to jury trial extends to the amount of punitive damages. 938 F2d at 506. In Kennon, a jury awarded compensatory damages of $\$ 20,750$. On appeal, the territorial supreme court held that the damages were excessive and reduced the judgment to $\$ 10,750$, without allowing the plaintiff to choose a new trial instead. 131 US at 24. The United States Supreme Court held that this reduction violated the Seventh Amendment. 131 US at 27-30. For two reasons, Kennon does not indicate that the Seventh Amendment entitles a party to a jury determination of the amount of punitive damages. First, there is no indication that the case involved an award of punitive damages. Second, what issues were triable to a jury was not in question; the issue of damages had been submitted to the jury. The Supreme Court's decision was based on the appellate court's action in substituting its estimate of the damages for the jury's and not affording the plaintiff the opportunity for a new trial if he found unacceptable whatever remittitur the court ordered. See 131 US at 29-30. Kennon is properly understood as a decision based on the Re-examination Clause rather than the Jury Trial Clause.

\$2 415 US 189, 189-90 (1974).

${ }^{2} 42$ USC § 3604(a) (1994). 
damages (which the statute permitted in the amount of $\$ 1,000$ or less). The prayer for injunctive relief was decided before trial, and at trial the plaintiff sought to recover compensatory as well as punitive damages. ${ }^{94}$ The trial court refused the defendants' request for a jury trial..$^{95}$ After a bench trial, it found no actual damages but awarded $\$ 250$ in punitive damages. ${ }^{96}$

The Supreme Court held that the defendants should have been afforded a jury trial. "The Seventh Amendment does apply," the Court declared, "to actions enforcing statutory rights, and requires a jury trial upon demand, if the statute creates legal rights and remedies, enforceable in an action for damages in the ordinary courts of law. ${ }^{\text {"97 }}$

The Court concluded that the action was one to enforce "legal rights. ${ }^{\text {"98 }}$ First, "[a] damages action under the statute sounds basically in tort-the statute merely defines a new legal duty," and the cause of action is "analogous to a number of tort actions recognized at common law. ${ }^{\text {p99 }}$ Second, and according to the Court more important, "the relief sought here-actual and punitive damages-is the traditional form of relief offered in the courts of law." 100 The Court also commented that, whatever might be the merit of circuit court decisions that had characterized backpay awarded in Title VII employment discrimination cases as "equitable," "there is surely no basis for characterizing the award of compensatory and punitive damages here as equitable relief."101

Like Barry, Curtis does not establish that the Seventh Amendment entitles a party to have a jury set punitive damages. In Curtis the trial court had decided all issues without a juryincluding whether the defendants had discriminated against the plaintiff because of her race, whether she had suffered actual damages, whether punitive damages were warranted, and if so what the amount of punitive damages should be. ${ }^{102}$ In holding that the defendants had been improperly denied a jury trial, the Supreme Court did not specify whether a judge or a jury should determine the amount of punitive damages. ${ }^{103}$

24 415 US at 190 \& $n 1$.

${ }^{2}$ Id at $190-91$.

${ }^{\infty}$ Id at 191.

${ }^{97}$ Id at 194 .

${ }^{98}$ Id at 195.

${ }^{\infty}$ Id.

${ }^{100}$ Id at 196 (footnote omitted).

${ }^{101}$ Id at 197 (footnote omitted).

${ }^{102}$ See id at 191.

${ }^{103}$ See id at 198. 
In defending the denial of a jury trial, the plaintiff had stressed in the Supreme Court that the only damages she sought in her complaint were punitive damages. ${ }^{104}$ Significantly, the Court did not state that it made no difference whether only punitive damages were sought, but instead noted that the plaintiff "later sought to recover actual damages as well," that the pretrial order listed actual damages as an issue to be tried, and that at trial the plaintiff unsuccessfully attempted to prove such damages. ${ }^{105}$

In distinguishing fair housing actions under Title VIII from employment actions for reinstatement and backpay under Title VII (which several courts of appeals had held did not trigger the right to a jury trial), ${ }^{106}$ the Curtis Court stressed that "the decision whether to award backpay is committed to the discretion of the trial judge," whereas "[t]here is no comparable discretion [under Title VIII]: if a plaintiff proves unlawful discrimination and actual damages, he is entitled to judgment for that amount." ${ }^{107}$ The Court's distinction depended on the presence of a claim for actual damages. Furthermore, in this respect punitive damages are similar to backpay under Title VII, not to actual damages under Title VIII. Punitive damages are awarded as a matter of discretion; there is no entitlement to them. ${ }^{108}$

The Court also stated that "[w]e need not, and do not, go so far as to say that any award of monetary relief must necessarily be 'legal' relief." 109 Immediately following that statement, the Court cited two of its prior decisions and, in a footnote, page 414 of the Fifth Circuit's decision in Swofford $v B \& W$, Inc. ${ }^{110}$ The Fifth Circuit stated there that the Supreme Court's decisions in Beacon Theatres, Inc $v$ Westover ${ }^{111}$ and Dairy Queen, Inc $v$ Wood ${ }^{112}$

${ }^{104}$ See id at $190 \mathrm{n} 1$.

${ }^{105} \mathrm{Id}$.

${ }^{106}$ See id at $196 \& \mathrm{n} 13$. In 1991, Title VII was amended to permit recovery of compensatory and punitive damages, and to afford a right to a jury trial when damages are sought. Civil Rights Act of 1991, Pub L No 102-166, § 102, 105 Stat 1071 (1991), codified at 42 USC $\S 1981$ a (1994).

${ }^{107}$ Curtis, 415 US at 197.

${ }^{109}$ See, for example, Restatement (Second) of Torts $\S 908$ comment d (1979); Shepherd Components, Inc $v$ Brice Petrides-Donohue \& Associates, Inc, 473 NW2d 612, 619 (Iowa 1991) ("We have stated that punitive damages are not allowed as a matter of right and are discretionary."); Alabama Power Co v Rembert, 282 Ala 5, 208 S2d 205, 206 (1968) ("Punitive damages are not recoverable as a matter of right except as provided by statute.").

${ }^{109}$ Curtis, 415 US at 196.

${ }^{110} 336$ F2d 406, 414 (5th $\mathrm{Cir}$ 1964). The other cases cited were Mitchell $v$ De Mario Jewelry, Inc, 361 US 288 (1960), and Porter $v$ Warner Holding Co, 328 US 395 (1946).

"11 359 US 500 (1959).

${ }^{112} 369$ US 469 (1962). 
had not "converted typical non-jury claims, or remedies, into jury ones" and had not "suddenly converted any money request into a money claim triable by jury."113 Moreover, the Swofford court had made those statements in support of its conclusion that "exemplary damages and attorneys' fees are not money claims triable by jury, although they are awarded in a 'legal' action."114

The Supreme Court's citation of Swofford, together with the care the Court took to point out that the issue of actual damages had been tried, ${ }^{115}$ suggests that the Court did not intend to decide whether there is a right to have a jury set punitive damages.

\section{TULL V UNITED STATES}

Not only has the Supreme Court never held that the Seventh Amendment guarantees a right to a jury trial on the amount of punitive damages, but in its 1987 decision in Tull $v$ United States, the Court ruled that the Seventh Amendment does not entitle a defendant to have a jury determine the amount of a civil penalty. ${ }^{116}$

Tull involved an action by the federal government against a real estate developer, Edward Tull, for a civil penalty under the Clean Water Act ("CWA"). ${ }^{117}$ The government sought a penalty of nearly $\$ 23$ million. ${ }^{118}$ The trial court denied Tull's demand for a jury trial and, after a bench trial, held him liable and assessed a . penalty of $\$ 325,000 .^{119}$

In an opinion by Justice Brennan, the Supreme Court held that Tull had a right to a jury trial on his liability for a penalty, ${ }^{120}$ but not on the amount of the penalty. ${ }^{121}$ It was permissible, the Court ruled, for Congress to vest trial judges with the power to set the amount of penalties under the CWA. ${ }^{122}$ The Court explained that having the jury "determine the remedy in a trial in

${ }^{123}$ Swofford, 336 F2d at 414.

"II Id at 413 (emphasis added). Swofford involved a claim of patent infringement, but the court's holding that there was no right to a jury trial on exemplary damages was based on the nature of that remedy, not on the nature of the claim; the court specifically noted that "[a] claim for damages based upon a charge of infringement of patent is plainly a 'legal' claim." Id at 410 n 5. The opinion in Swofford was written by Judge Rives and joined by Chief Judge Tuttle and Judge Wisdom.

${ }^{115}$ See Curtis, 415 US at $190 \mathrm{n} 1$.

${ }^{116} 481$ US at $426-27$.

${ }^{217} 33$ USC $\S 1319$ (d) (1994). See Tull, 481 US at 414.

${ }^{118}$ Tull, 481 US at 415.

${ }^{119} \mathrm{Id}$.

${ }^{120}$ Id at $424-25$.

${ }^{121}$ Id at $425-27$.

${ }^{122} \mathrm{Id}$ at 426-27. 
which it must determine liability" is not "necessary" "to preserve the 'substance of the common law right of trial by jury."'123 In a footnote, the Court added the very broad statement that "[n]othing in the Amendment's language suggests that the right to a jury trial extends to the remedy phase of a civil trial." ${ }^{2124}$ The Court said it had been "presented with no evidence that the Framers meant to extend the right to a jury to the remedy phase of a civil trial. $\$ 25$

The Court went on to explain:

The assessment of a civil penalty is not one of the "most fundamental elements." Congress' authority to fix the penalty by statute has not been questioned, and it was also the British practice. In the United States, the action to recover civil penalties usually seeks the amount fixed by Congress. The assessment of civil penalties thus cannot be said to involve the "substance of a common-law right to a trial by jury," nor a "fundamental element of a jury trial."126

The Court added two other justifications for its conclusion that Tull had no right to have a jury determine his penalty. First, "[s]ince Congress itself may fix the civil penalties, it may delegate that determination to trial judges." 127 Second, "[i]n this case, highly discretionary calculations that take into account multiple factors are necessary in order to set civil penalties under the Clean Water Act. These are the kinds of calculations traditionally performed by judges." ${ }^{28}$

Although Tull involved a statutory civil penalty rather than punitive damages, the Court's opinion specifically notes that "the remedy of civil penalties is similar to the remedy of punitive damages, another legal remedy that is not a fixed fine. ${ }^{.129}$ More-

${ }^{123}$ Id at 425-26 (footnotes omitted), quoting Colgrove, 413 US at 157.

${ }^{22} 481$ US at $426 \mathrm{n} 9$.

${ }^{225}$ Id.

${ }^{126}$ Id at 426 (citations omitted).

${ }^{127}$ Id at 427.

${ }^{12}$ Id, citing. Albemarle Paper Co v Moody, 422 US 405, 442-43 (1975) (Rehnquist concurring). In his concurring opinion in Albemarle, Justice Rehnquist suggested that if backpay were routinely awarded under Title VII upon a finding of discrimination, rather than on a case-by-case basis in the discretion of the court, the right to a jury trial would be triggered. 422 US at 443. (In 1991, Congress amended Title VII to provide a right to a jury trial whenever damages are sought. See note 106.)

${ }^{120} 481$ US at $422 \mathrm{n} 7$. See also id at 422 (describing punitive damages as an example of a remedy "intended to punish culpable individuals" that was "issued by courts of law, not courts of equity"); Minneapolis and St Louis Railway Co v Beckwith, 129 US 26, 36 (1889) (describing punitive damages as "one mode of imposing a penalty for the violation of duty"). The statements in Tull about punitive damages appear in the part of the opinion 
over, while two dissenting Justices argued that the decision was inconsistent with the traditional treatment of punitive damages, ${ }^{130}$ the majority did not distinguish punitive damages or indicate that its decision would have no impact on claims for punitive damages. When Tull was decided, the Supreme Court had begun to devote increasing attention to cases involving large awards of punitive damages. ${ }^{131}$ The Court surely would have been aware of the potential implications of its decision for punitive damages; indeed, its broad language questioning whether the right to jury trial extends to the determination of remedies at all ${ }^{132}$ may well have been included for the very purpose of inviting a rethinking of the treatment of punitive damages. In light of Tull, as well as the recent statement of three Justices that "the level of punitive damages is not really a 'fact' 'tried' by the jury, ${ }^{1133}$ whether a party has a right under the Seventh Amendment to have a jury set punitive damages is very much an open question. ${ }^{134}$

holding that the defendant had a right to have a jury decide his liability for a penalty. 481 US at $422-25$.

${ }^{130}$ See 481 US at 428 (Scalia, joined by Stevens, concurring in part and dissenting in part) ("I can recall no precedent for judgment of civil liability by jury but assessment of amount by the court. Even punitive damages are assessed by the jury when liability is determined in that fashion.").

${ }^{131}$ Three weeks before Tull was decided, the Court decided a case involving what was then the largest punitive damages award ever, a $\$ 3$ billion award against Texaco. See Pennzoil Co v Texaco, Inc, 481 US 1, 4 (1987). See also Bankers Life \& Casualty Co $v$ Crenshaw, 480 US 915 (1987) (noting probable jurisdiction in case involving constitutional challenges to \$1.6 million punitive award), decided on other grounds, 486 US 71, 80 (1988); Aetna Life Insurance Co v Lavoie, 475 US 813, 816 (1986) (involving a \$3.5 million punitive award).

${ }^{132}$ See Tull, 481 US at $425-26$.

${ }^{133}$ Gasperini, $116 \mathrm{~S} \mathrm{Ct}$ at 2235 (Scalia, joined by Rehnquist and Thomas, dissenting).

${ }^{134}$ See Colleen P. Murphy, Integrating the Constitutional Authority of Civil and Criminal Juries, 61 Geo Wash L Rev 723, 803 (1993) (arguing that the Seventh Amendment does not require that a jury determine the amount of punitive damages). In 1989, two years after Tull, a panel of the Fourth Circuit held, in Shamblin's Ready Mix, Inc $v$ Eaton Corp, 873 F2d 736, 742 (4th Cir 1989) (opinion by Butzner), that there is no right to a jury trial on the amount of punitive damages. In 1991, the Fourth Circuit, sitting en banc, overruled Shamblin's. Defender Industries, Inc v Northwestern Mutual Life Insurance Co, 938 F2d 502, 507 (4th Cir 1991). In Defender Industries, the trial court, upon finding the jury's punitive damages award to be grossly excessive, had not followed the familiar procedure of ordering a new trial unless the plaintiff accepted a remittitur, but instead had ordered that judgment be entered in a reduced amount. Id at 505. Because the jury had been asked to return a verdict assessing punitive damages, with no suggestion that the verdict would be simply advisory, the Fourth Circuit could have overturned the trial court's ruling solely on the basis of the Re-examination Clause. Compare Browning-Ferris Industries of Vermont, Inc $v$ Kelco Disposal, Inc, 492 US 257, 280 \& n 26 (1989) (relying in part on Seventh Amendment in according considerable deference to trial court's denial of new trial motion in case involving large punitive damages award). But the Fourth Circuit went further, concluding that "assessment by a jury of the amount of punitive damages is 


\section{Punitive Damages in Eighteenth CENTURY ENGLAND}

Since the existence of a right to have a jury set punitive damages is an open question under Supreme Court precedent, the critical questions are whether jury determination of the amount of punitive damages was within "the 'substance of the common law right of trial by jury, ${ }^{\mathrm{m} 135}$ and was one of the "most fundamental elements" ${ }^{136}$ of the jury-trial system in eighteenth century England. While the vagueness of these formulations means that their application to specific issues will almost always be debatable, they would appear to indicate that there is no right under the Seventh Amendment to have a jury set punitive damages.

\section{A. Absence of Right to Have a Jury Determine Damages}

In his opinion for the Court in Tull, Justice Brennan strongly questioned whether the Seventh Amendment was intended to guarantee a right to a jury in "the remedy phase of a civil trial, ${ }^{137}$ but failed to cite any authority suggesting that the Jury Trial Clause was not intended to apply to determinations of remedy. Perhaps because of the terseness of the Court's discussion, this part of Tull has not been accorded much significance in subsequent cases in the lower federal courts or in state courts concerning the existence of a right to have a jury set punitive damages. ${ }^{138}$

The distinction suggested in Tull does in fact find support in the English common law. The common-law allocation of responsibility to determine damages calls into question whether the Seventh Amendment even guarantees the right to have a jury set compensatory damages, let alone punitive damages.

an inherent and fundamental element of the common-law right to trial by jury." $938 \mathrm{~F} 2 \mathrm{~d}$ at 507. See also Johnson v Hugo's Skateway, 974 F2d 1408, 1416 (4th Cir 1992) (en banc); Mattison v Dallas Carrier Corp, 947 F2d 95, 107-08 (4th Cir 1991).

More recently, a Fourth Circuit panel has relied upon Tull, notwithstanding Defender Industries, in adopting a novel and more demanding standard to govern post-trial review of punitive damages awards. Atlas Food Systems and Services $v$ Crane National Vendors, 99 F3d 587, 594-95 (4th $\mathrm{Cir} 1996$ ) (discussed in note 9).

${ }^{135}$ Tull, 481 US at 426, quoting Colgrove, 413 US at 157.

${ }^{136}$ Galloway, 319 US at 392.

${ }^{137} 481$ US at $426 \mathrm{n} 9$.

${ }^{138}$ See, for example, Defender Industries, 938 F2d at 506 (noting that "Tull does contain some rather broad language," but concluding that Tull "cannot stand for the proposition that a plaintiff bringing a state common-law cause of action does not have a right to a jury determination of the amount of punitive damages"). 
In jury trials at common law, the jury could award damages. ${ }^{139}$ When it did so, the amount of its award was subject to only limited review. ${ }^{140}$ But there was no right to have damages determined in a trial by jury.

Damages were frequently assessed in a separate proceeding conducted by a sheriff rather than in a trial by jury. This separate proceeding was held when a plaintiff obtained an interlocutory judgment by confession, default, or the overruling of a demurrer. ${ }^{141}$ Following the interlocutory judgment, damages were determined pursuant to a writ of inquiry. ${ }^{142} \mathrm{~A}$ writ of inquiry was issued by the court in which the action was pending and was executed by the sheriff. It stated that "the plaintiff ought to recover his damages .... But because it is unknown what damages he hath sustained ...., the sheriff is commanded, that by the oath of twelve honest and lawful men of his county, he diligently inquire the same; and return the inquisition into court." ${ }^{243}$ The inquest jury sometimes had more than twelve members. ${ }^{144}$

When a writ of inquiry was executed, the inquiry into damages was conducted before the sheriff or an undersheriff. ${ }^{145}$ According to one estimate, in the seventeenth century there were five times as many inquiries into damages before sheriffs as there were trials involving damages before nisi prius judges. ${ }^{146}$

The English courts recognized that there was "a difference between a principal verdict of a jury, and a writ of inquiry of

${ }^{130}$ See, for example, Grey $v$ Grant, 2 Wils KB 251, 95 Eng Rep 794, 795 (KB 1764).

${ }^{140}$ See Sharpe $v$ Brice, 2 Black W 942, 96 Eng Rep 557, 557 (CP 1774); Beardmore $v$ Carrington, 2 Wils KB 244, 95 Eng Rep 790, 793 (KB 1764).

${ }^{14}$ See Clinton W. Francis, The Structure of Judicial Administration and the Development of Contract Law in Seventeenth Century England, 83 Colum L Rev 35, 64 \& n 139 (1983); Thomas Chitty, 2 Archibold's Practice of the Courts of Queen's Bench in Personal Actions and Ejectment 930, 982-86 (H. Sweet 11th ed 1862). If, however, issues of fact were tried to a jury before the argument on a demurrer and resolved in the plaintiffs favor, the jury trying such issues would also assess damages. James Stephen, Lush's Practice of the Superior Courts of Common Law at Westminster 596 (C. Reader $2 d$ ed 1856).

${ }^{142}$ See William Blackstone, 3 Commentaries on the Laws of England 397-98 (Chicago 1979); Francis, 83 Colum L Rev at 64 . An exception developed in the eighteenth century for actions in which the damages could be calculated with certainty. Damages in such cases were calculated by a court officer. See Clinton W. Francis, Practice, Strategy, and Institution: Debt Collection in the English Common-Law Courts, 1740-1840, $80 \mathrm{Nw}$ U L Rev 807, 815 n 20 (1986); Chitty, 2 Archibold's Practice at 983-84.

${ }^{143}$ William Tidd, 1 The Practice of the Courts of King's Bench and Common Pleas 573 (Robert E. Small 4th ed 1856).

${ }^{14}$ See, for example, Proceedings on a Writ of Inquiry of Damages between His Royal Highness James Duke of York, in an Action upon the Statute de Scandalis Magnatum, and Titus Oates, 3 St Trials 987, 987 (KB 1684) (inquest jury comprised of fifteen men).

${ }^{145}$ See Francis, 83 Colum L Rev at 64; Chitty, 2 Archibold's Practice at 987.

${ }^{146}$ See Francis, 83 Colum $L$ Rev at 64. 
damages; the latter being only an inquest of office to inform the conscience of the Court, and which they might have assessed themselves without any inquest at all. ${ }^{147}$ It was recognized that courts, "if they please, may themselves assess the damages." Although courts seldom set aside a verdict returned pursuant to a writ of inquiry, ${ }^{149}$ their power to assess damages themselves without an inquest was not questioned. ${ }^{150}$

At common law, when a defendant contested liability but did not file a demurrer, damages as well as liability were decided in a jury trial. ${ }^{151}$ But the practice following default, confession of judgment, and overruling of a demurrer suggests that in other cases damages were decided by a jury as a matter of convenience, rather than because a party was deemed to have a right to have a jury assess them. ${ }^{152}$

The case law in this country concerning defaults supports this interpretation. In 1797 , in a case in which a federal trial

${ }^{147}$ Beardmore, 95 Eng Rep at 792. See also Bruce $v$ Rawlins, 3 Wils KB 61, 95 Eng Rep 934, 934 (KB 1770); Hewit v Mantel, 2 Wils KB 372, 95 Eng Rep 868, 870 (KB 1768).

${ }^{148}$ Bruce, 95 Eng Rep at 934. See Hewit, 95 Eng Rep at 870; Beardmore, 95 Eng Rep at 792; Chitty, 2 Archibold's Practice at 992-93 (cited in note 141). See also Welch $v$ Tennessee Valley Authority, 108 F2d 95, 99 (6th Cir 1939) ("Courts of England, at the time of the adoption of the Constitution, did not lack the power to fix damages in many cases at common law. They frequently fixed the amount on judgment by default and on demurrer."); Editorial, Assessment of Damages Upon Default, 7 Yale L J 311, 311 (1898) ("At common law, upon a default, the assessment of damages, whether liquidated or unliquidated, was never referable of right to a jury.").

${ }^{19}$ See Francis, 83 Colum L Rev at 90-91 (cited in note 141). See also Burges $v$ Nightingale, Barnes 230, 94 Eng Rep 890, 890 (CP 1736) ("Where the jury find any damages, the inquisition must stand.").

${ }^{150}$ In Dimick v Schiedt, 293 US 474 (1935), Justice Sutherland's opinion for the Court discussed writs of inquiry as follows:

The power of the court to increase or diminish damages assessed upon a writ of inquiry was likewise upheld; but this upon the ground that the justices might themselves have awarded damages without the writ, and the inquisition, therefore, was nothing more than an inquest for their information. But even this rule seems long since to have fallen into disuse, the more modern practice being to award a new writ of inquiry in all cases in which the court would award a new trial.

Id at 478-79 (citations omitted). The Court did not suggest that as of 1791 any question had been raised as to the power of English judges to assess damages themselves without a writ of inquiry, or that the English courts had recognized a right to have damages assessed in a jury trial rather than pursuant to a writ of inquiry.

${ }^{151}$ See Tullidge $v$ Wade, 3 Wils KB 18, 95 Eng Rep 909, 909 (KB 1769).

${ }^{152}$ See Raymond $v$ Danbury \& NR Co, 20 F Cases 332, 333 (Cir Ct D Conn 1877) ("The assessment of damages by a jury, in actions, of tort, was . . . a matter of practice, and not of right."); Pierre $v$ Eastern Air Lines, Inc, 152 F Supp 486, 488 (D NJ 1957) ("At common law the assessment of damages in a default, in tort and in contract, was not considered a function of the jury and stood upon a different footing from the trial of issues of fact. The measuring of damages by a jury, therefore, would seem to be a matter of practice rather than of right."). 
court assessed damages itself after a default, the Supreme Court affirmed the judgment, ${ }^{153}$ necessarily rejecting the defendant's claim that damages should have been assessed by the jury. ${ }^{154}$ The defendant had relied upon the provision of the Judiciary Act of 1789 requiring that all issues of fact be decided by a jury. ${ }^{155}$

Similarly, the lower federal courts have almost uniformly held that the Seventh Amendment does not confer a right to have a jury determine damages after a default. ${ }^{156}$ The rule that there is no right to a jury trial after a default has been applied not just against defaulting defendants, but against plaintiffs seeking a jury trial on damages after a defendant's default. ${ }^{157}$ These decisions thus cannot be attributed to an unstated doctrine of waiver or forfeiture; they instead are a latter-day reflection of the absence at common law of a right to a jury trial on damages.

\section{B. Considerations Peculiar to Punitive Damages}

The absence at common law of a right to have the amount of damages decided by a jury suggests that it might even be consistent with the Seventh Amendment for federal judges to determine the amount of compensatory damages. ${ }^{158}$ But whether or not

${ }^{153}$ See Brown v Van Braam, 3 US (3 Dall) 344, 356 (1797).

is See id at 347-48 (stating defendant's claim).

${ }^{15 s}$ See id at 352, citing An Act to regulate Processes in the Courts of the United States, $\S 34,1$ Stat 92 (1789).

${ }^{15 s}$ See Goldman, Antonetti, Ferraiuoli, Axtmayer \& Hertell $v$ Medfit International, Inc, 982 F2d 686, 692 n 15 (1st Cir 1993); Adriana International Corp v Thoeren, 913 F2d 1406, 1414 (9th Cir 1990); Eisler v Strizler, 535 F2d 148, 153 (1st Cir 1976); Henry v Sneiders, 490 F2d 315, 318 (9th Cir 1974); Midland Contracting Co v Toledo Foundry \& Machine Co, 154 F 797, 799-800 (7th Cir 1907) (discussing Seventh Amendment rights, although deciding case on state-law grounds); Frankart Distributors, Inc $v$ Levitz, $796 \mathrm{~F}$ Supp 75, 76 (E D NY 1992); Kormes $v$ Weis, Voisin \& Co, Inc, 61 FRD 608, 609 (E D Pa 1974); Gill $v$ Stolow, 18 FRD 508, 510 (S D NY 1955), revd on other grounds, 240 F2d 669, 670 (2d Cir 1957). See FRCP 55(b)(2) (providing for jury trial on the issue of damages after a default only when required by a federal statute). But see Byrd $v$ Keene Corp, 104 FRD 10,12 (E D Pa 1984) (noting that although the decision whether to enter a default judgment is left to the courts discretion, the "parties may exercise their statutory and constitutional right to jury trial at that hearing").

${ }^{i s 7}$ See Benz v Skiba, Skiba \& Glomski, 164 FRD 115, 116 (D Me 1995); Johnson v Bridgeport Deoxidized Bronze \& Metal Co, 125 F 631, 632 (Cir Ct D Conn 1903); Raymond, 20 F Cases at 333-34. See In re Dierschke, 975 F2d 181, 185 (5th Cir 1992) ("It is also 'clear... that in a default case neither the plaintiff nor the defendant has a constitutional right to jury trial on the issue of damages,"' quoting James W. Moore, 5 Moore's Federal Practice \& 38.19[3] (Matthew Bender 1996)).

${ }^{1 s s}$ In Dimick $v$ Schiedt, 293 US 474 (1935), however, which held that additur violates the Re-examination Clause, the five-Justice majority stated that, when a verdict is excessive or inadequate, "both parties remain entitled as they were entitled in the first instance, to have a jury properly determine the question of liability and the extent of the injury by an assessment of damages." Id at 486 (emphasis added). (Dimick did not involve an award 
such a practice would be permissible, there are considerations peculiar to punitive damages that confirm that the Seventh Amendment should not be interpreted to require that punitive damages be set by juries.

First, the English cases prior to 1791 that endorsed punitive damages (which were then referred to as exemplary damages) spoke of the power of the jury to award such damages, not of any right of a party to have a jury set them. For example, in Wilkes $v$ Wood, ${ }^{159}$ the Court of King's Bench stated that "a jury have it in their power to give damages for more than the injury received." Moreover, punitive damages were not restricted to jury trials. In Benson $v$ Frederick, ${ }^{160}$ one of the early decisions upholding a damage award in excess of the plaintiff's loss, the damages had been determined not in a trial by jury but in an inquest before a jury pursuant to a writ of inquiry.

The absence of English authority recognizing a right to have a jury determine the amount of punitive damages is not surprising in light of the English practice in criminal cases. Judges, not juries, determined sentences (though juries sometimes refused to find the defendant guilty because of concern about the harsh punishment he could face if convicted). ${ }^{161}$ Since there was no right to have a jury determine the degree of punishment in criminal cases-where a defendant's life or liberty was at stake-it would have been anomalous to recognize a right to have a monetary punishment fixed by a jury.

Second, although the common law had developed over several centuries, punitive damages were first recognized in $1763 .{ }^{162}$ The awards of punitive damages returned in jury trials in a number of cases between 1763 and 1791 hardly made jury determination of such damages one of the most fundamental elements of the jury-trial system. ${ }^{163}$

of punitive damages.) In 1791, compensation was also a basic and long-established purpose of common law causes of action. See, for example, Anonymous, YB $6 \mathrm{Edw} 4$, fol 7, pl 18 (KB 1466). A powerful argument can be made that the jury's role would be impermissibly trivialized if even compensatory damages were determined by the judge.

${ }^{159}$ Lofft 1, 98 Eng Rep 489, 498 (CP 1763).

${ }^{160} 3$ Burr 1845, 97 Eng Rep 1130, 1130 (KB 1766).

${ }^{161}$ See Leon Radzinowicz, 1 A History of English Criminal Law and its Administration from 1750 93-95 (Stevens 1948) (discussing acquittals in cases involving small offenses punishable by death).

${ }^{162}$ See Wilkes, 98 Eng Rep at 498; Huckle v Money, 2 Wils KB 205, 95 Eng Rep 768, 769 (KB 1763).

${ }^{163}$ In Defender Industries, Inc $v$ Northwestern Mutual Life Insurance Co, 938 F2d 502, 507 (4th Cir 1991) (en banc), the Fourth Circuit cited, as support for its conclusion that the Seventh Amendment confers a right to have a jury set punitive damages, the Supreme 
As the Supreme Court stressed in Galloway $v$ United States, the rules of the common law "were constantly changing and developing during the late eighteenth and early nineteenth centuries." 164 Because capacity for change was an inherent part of the common law, the common law of England in 1791 possessed the capacity to adopt changes in the procedures for resolving particular issues, including punitive damages. Since punitive damages were only a recent arrival on the legal scene, had not been awarded exclusively in jury trials, and had not been declared to be triable to a jury as of right, ${ }^{165}$ it is not reasonable to interpret a constitutional amendment preserving the right of trial by jury in suits "at common law" as forever requiring that juries set such damages.

Third, there are important differences between punitive damages under modern American law and punitive damages under eighteenth century English law. As Professor Charles McCormick noted, "[i]t is only in America that the cases clearly have separated exemplary from compensatory damages."166 In this country punitive damages are the subject of separate instructions, and in nearly all states the jury, if it chooses to award such damages, identifies in its verdict separate sums for compensatory and punitive damages. In contrast, in eighteenth century England, punitive damages typically were not a separate element of recovery. In Huckle $v$ Money, ${ }^{167}$ one of the first cases to recognize such damages, the jury returned an undifferentiated verdict of $£ 300$. Lord Camden had instructed the jurors that "they were not bound to any certain damages"; ${ }^{168}$ there was no instruction to consider separately what damages the jurors might deem appropri-

Court's statement in Pacific Mutual Life Insurance Co $v$ Haslip, 499 US 1, 15 (1991), that "[u]nder the traditional common-law approach, the amount of the punitive award is initially determined by a jury." In context, however, it is apparent that the Court's statement in Haslip-which involved a challenge under the Due Process Clause of the Fourteenth Amendment to a punitive damages award in a trial in state court not subject to the Seventh Amendment-was not directed to the English common law, but to the common law in the United States prior to the adoption of the Fourteenth Amendment in 1868. The Court had no reason to consider, and there is no indication that it did consider, whether jury determination of the amount of punitive damages was a significant part (if it was any part at all) of the right to jury trial in eighteenth century England.

${ }^{164} 319$ US at 391 (footnote omitted). See also Gasperini, $116 \mathrm{~S} \mathrm{Ct}$ at $2224 \mathrm{n} 20$ (meaning of the Seventh Amendment not fixed as of 1791); Wolfram, 57 Minn L Rev at 736-37 (cited in note 26) (arguing that the understanding in 1791 of "common law" involved "flexibility and capacity for growth in order to respond to changing social pressures").

${ }^{165}$ See text accompanying notes 139-53 and 159-64.

${ }^{166}$ Charles T. McCormick, Handbook on the Law of Damages 278 (West 1935).

${ }^{167} 2$ Wils KB 205, 95 Eng Rep 768 (KB 1763).

${ }^{168}$ Id at 769. 
ate as punishment. Similarly, the report of Wilkes $v$ Wood, a related case in which the jury awarded $£ 1000$, indicates that Lord Pratt gave instructions to the jury to the effect that

a jury have it in their power to give damages for more than the injury received. Damages are designed not only as a satisfaction to the injured person, but likewise as punishment to the guilty, to deter from any such proceeding for the future, and as a proof of the detestation of the jury to the action itself. ${ }^{169}$

This instruction identified punishment as an additional purpose of damages, but did not ask the jury to return a separate award of punitive damages.

In several of the pre-1791 English cases that endorsed punitive damages, not only were such damages not a distinct element of recovery, but the rationale of punishment or setting an example was blended with the compensatory rationale of remedying an insult to the plaintiff. For example, in Tullidge $v$ Wade ${ }^{170}$ the court upheld a jury's verdict of $£ 50$ against a defendant who "got [the plaintiff's daughter] with child." Again there is no indication that the jury was instructed to consider what sum should be awarded as punitive damages or as punishment. And two of the three judges stressed the insult to the plaintiff in concluding that the verdict should stand. ${ }^{171}$

\section{Criminal Cases}

A comparison to criminal cases is also instructive. Just as the Seventh Amendment preserves the right to jury trial in civil cases, both the Sixth Amendment and Article III, Section 2, guarantee the right to jury trial in criminal cases. Indeed, the Supreme Court has called the Sixth Amendment right to jury

${ }^{169} 98$ Eng Rep at 498-99.

${ }^{170} 3$ Wils KB 18, 95 Eng Rep 909, 909 (KB 1769).

${ }^{171}$ See id at 909 (opinion by Wilmot) ("the plaintiff having received this insult in his own house"), 910 (opinion by Bathurst) ("In actions of this nature, and of assaults, the circumstances of time and place, when and where the insult is given, require different damages."). See also Benson, 97 Eng Rep at 1130 (opinion by Lord Mansfield) (arguing that the plaintiff, "though not much hurt indeed, was scandalized and disgraced"); Grey, 95 Eng Rep at 795 ("[T]he plaintiff has been used unlike a gentleman by the defendant."). In 1935, Professor McCormick wrote that "[i]n England . . . it is still not entirely clear whether the accepted theory [of punitive damages] is that they are a distinct and strictly punitive element of the recovery, or they are merely a swollen or 'aggravated' allowance of compensatory damages permitted in cases of outrage." McCormick, Handbook at 278 (cited in note 166) (footnote omitted). 
trial "fundamental to the American scheme of justice" and has held that that right-unlike the Seventh Amendment right to jury trial-must be honored in state as well as federal court. ${ }^{172}$

But the Court also has held that the Sixth Amendment does not give a criminal defendant a right to have a jury determine his sentence. ${ }^{173}$ Even in a capital case, it is permissible to assign full responsibility for deciding the defendant's sentence to the judge.$^{174}$ If a citizen whose life or liberty is at stake does not have a right to have a jury determine his punishment, it is difficult to fathom why a citizen seeking punitive damages or seeking to avoid their imposition should have a right to have a jury determine the amount.

\section{THE REASONS WHY JUDGES RATHER THAN JURIES SHOULD SET PUNITIVE DAMAGES}

If the Seventh Amendment does not dictate that juries set punitive damages, then the allocation of power to set such damages, in cases brought in federal court, is a matter of policy. This Part first will examine several considerations supporting allocation of this power to trial judges, and then show that the general justifications for jury trials in civil cases do not outweigh those considerations.

A. Policies Supporting Assessment of Punitive Damages by Judges

More than a century ago, the Supreme Court of Texas observed:

A power such as may be exercised by juries in awarding exemplary damages is liable to great abuse,-may often lead to great oppression. ... In cases based on facts which merit condemnation, or even punishment, though not by law constituting crime, juries, under commendable impulses, but with judgment warped by passion, no doubt often render excessive verdicts. ${ }^{175}$

${ }^{172}$ Duncan v Louisiana, 391 US 145, 149 (1968).

${ }^{173}$ See Walton v Arizona, 497 US 639, 647-49 (1990); Hildwin v Florida, 490 US 638, 640-41 (1989) (per curiam); McMillan v Pennsylvania, 477 US 79, 93 (1986); Spaziano $v$ Florida, 468 US 447, 459 (1984).

${ }^{174}$ Walton, 497 US at 647-49; Hildwin, 490 US at 640-41.

${ }^{175}$ Tynberg $v$ Cohen, 76 Tex 409, 13 SW 315, 317 (1890). 
This observation was made in support of the need to exercise, "firmly and fearlessly," the power to grant a new trial when a jury's punitive damages award is excessive ${ }^{176}$ but it also points to a reason that judges are better equipped than juries to set punitive damages in the first place. Just as the Supreme Court has held that judges are better suited than juries to construe patents, ${ }^{177}$ judges are also better suited to mete out punishment. They are more likely to be able to base the severity of the penalty on a rational assessment of the facts, rather than an emotional reaction to the defendant's misconduct. As was said in an analysis of the allocation of power to determine sentences in criminal cases, "juries are more easily influenced by emotional factors than judges, who, due to their experience, are better able to make an objective determination of the penalty to be inflicted." "178

It might be objected that the argument proves too much, for emotional factors also may influence jury awards of compensatory damages, yet juries are nevertheless asked to set compensatory damages. But assigning the determination of punitive damages to an emotion-prone decisionmaker is much more troubling than assigning the determination of compensatory damages to such a decisionmaker. In the words of the Supreme Court, punitive damages are "private fines."179 But unlike criminal fines and civil statutory penalties, they are generally not subject to any cap. ${ }^{180}$ The criteria that govern the determination of the amount of punitive damages confer enormous discretion. ${ }^{181}$ Yet punitive damages

${ }^{176}$ Id (" $[T]$ here is no class of cases in which the conservatism of the judge should more frequently find field for action.").

${ }^{17}$ See Markman, $116 \mathrm{~S} \mathrm{Ct}$ at 1395 (holding that judges rather than juries should construe patents in part because "a jury's capability to evaluate demeanor, to sense the 'mainsprings of human conduct,' or to reflect community standards, are much less significant than a trained ability to evaluate the testimony in relation to the overall structure of the patent") (citations omitted).

${ }^{178}$ Comment, Consideration of Punishment by Juries, 17 U Chi L Rev 400, 406 (1950). See also Moreno $v$ Consolidated Rail Corp, 99 F3d 782, 792 (6th Cir 1996) (en banc) (declining to hold that punitive damages are available under the Rehabilitation Act of 1973, 29 USC $\S 794$ (1985 \& Supp 1997), in part because “ $[t]$ he whole issue of punitive damages is becoming an increasingly problematic one, of course, as a sort of game-show mentality leads some contemporary juries to award punitive damages in amounts that seem utterly capricious").

${ }^{179}$ Gertz v Robert Welch, Inc, 418 US 323, 350 (1974).

${ }^{180} \mathrm{~A}$ minority of jurisdictions have statutory caps on punitive damages in some or all actions. See, for example, Fla Stat Ann $\$ 768.73$ (West 1997); Tex Civ Pract \& Rem Code Ann $\S 41.008$ (Vernon 1997).

${ }^{181}$ See, for example, Guzman $v$ Western State Bank of Devils Lake, 540 F2d 948, 954 (8th $\mathrm{Cir}$ 1976) ("In reviewing an award of punitive damages there is no basis from which an appellate court may measure damage."); Rowlett $v$ Anheuser-Busch, Inc, 832 F2d 194, 207 (1st Cir 1987) (same). 
are awarded without the necessity for proof beyond a reasonable doubt and without many of the other protections afforded in criminal cases to minimize the risk of punishing the innocent. It is extremely problematic to give a broad power to punish to a decisionmaker that is particularly susceptible to passion and emotion, in a proceeding that lacks many of the safeguards that usually precede the meting out of punishment. ${ }^{182}$

A related consideration that favors having judges set punitive damages derives from the role that the defendant's wealth plays in setting punitive damages. In most civil cases, evidence of a party's wealth is inadmissible. ${ }^{183}$ "The underlying reason for the rule is that such evidence tends to inject into the case a foreign, diverting, and distracting issue which may effectuate prejudicial results." ${ }^{184}$ But when the amount of punitive damages is at issue, a plaintiff is allowed to introduce evidence of the defendant's finances, ${ }^{185}$ on the theory that "the degree of punishment or deterrence resulting from a judgment is to some extent in proportion to

${ }^{10}$ The National Law Journal's annual surveys of large jury verdicts, while perhaps not complete, suggest the frequency with which juries return enormous awards of punitive damages. The 1993 survey reported four punitive damages awards of $\$ 250$ million or more, three awards of approximately $\$ 100$ million, ten awards of between $\$ 20$ million and $\$ 100$ million, and ten awards of between $\$ 5$ million and $\$ 20$ million. Despite Tort Reform, Huge Verdicts Continue Climbing, Natl L J S2-S12, S14, S16-S17 (Jan 17, 1994). The 1994 survey reported the $\$ 5$ billion award in the Exxon Valdez case, a $\$ 1.2$ billion award in a suit for human rights abuses brought against the estate of Ferdinand Marcos, an award of $\$ 173$ million, sixteen awards of between $\$ 20$ million and $\$ 100$ million, and thirteen more awards of between $\$ 5$ million and $\$ 20$ million. Verdicts: The Big Numbers of 1994, Natl L J C2-C16 (Feb 6, 1995). The 1995 survey reported a $\$ 400$ million award, two $\$ 300$ million awards, a $\$ 175$ million award, six awards of between $\$ 50$ million and $\$ 70$ million, seven awards of between $\$ 20$ million and $\$ 25$ million, and seven awards of between $\$ 7$ million and $\$ 19$ million. Verdicts: The Big Numbers of 1995, Natl L J C2-C15 (Feb 5, 1996). The 1996 survey reported a $\$ 386$ million award, a \$210 million award, a \$200 million award, six awards of between $\$ 100$ million and $\$ 150$ million, seven awards of between $\$ 23$ million and $\$ 60$ million, seven awards of between $\$ 12$ million and $\$ 18$ million, and three awards of approximately $\$ 10$ million. Verdicts: The Big Numbers of 1996, Natl L J C2-C10, C12, C14 (Feb 10, 1997).

A study of jury awards in state courts of general jurisdiction in the seventy-five largest counties in cases involving tort, contract, and real property claims, for the year ended June 30, 1992, identified 364 awards of punitive damages; the mean award was $\$ 735,000$ and the median award \$50,000. Bureau of Justice Statistics Special Report: Civil Jury Cases and Verdicts in Large Counties 1, 8 (DOJ 1995).

${ }^{163}$ See, for example, Geddes, PMC v United Financial Group, 559 F2d 557, 560 (9th Cir 1977); Eisenhauer v Burger, 431 F2d 833, 837 (6th Cir 1970); Blankenship v Rowntree, 219 F2d 597, 598 (10th Cir 1955). See also Parkins v Brown, 241 F2d 367, 368 n 2 (5th Cir 1957) (allowing evidence of wealth "only if the evidence develops a case warranting the jury in awarding punitive or exemplary damages").

${ }^{184}$ Blankenship, 219 F2d at 598.

${ }^{18 s}$ See Gerald W. Boston, Punitive Damages in Tort Law § 32:1 at 2-3 (Clark, Boardman 1993). 
the means of the guilty person. ${ }^{3186}$ Whatever the merits of the theory, ${ }^{187}$ evidence that a defendant has a huge net worth often contributes to a staggering verdict.

The Supreme Court recognized this problem in Honda Motor Co v Oberg, ${ }^{188}$ in which it held that a state violates due process by letting juries set punitive damages but not permitting review by a trial or appellate court for excessiveness. The Court stressed that "the presentation of evidence of a defendant's net worth creates the potential that juries will use their verdicts to express biases against big businesses, particularly those without strong local presences. ${ }^{3189}$ Unless the amount of punitive damages is determined in a separate phase of the trial, it seems clear that admission of evidence of wealth also may skew the jury's assessment of liability for compensatory and punitive damages and of the amount of compensatory damages. The significant increase in income inequality among Americans since the $1960 \mathrm{~s}^{190}$ has likely exacerbated the risk created by admission of evidence of wealth.

Judges are better suited than juries to give appropriate weight to a defendant's finances. They are less likely to be swayed by arguments that seek to base the calculation of punitive damages on a percentage of the defendant's net wealth or income.

Because of their responsibility for sentencing in criminal cases and for imposing civil statutory penalties, judges ordinarily have much more experience than jurors in determining punishments and far more familiarity with the sanctions imposed for

${ }^{185}$ Restatement (Second) of Torts $\S 908$ comment e (1977).

${ }^{187}$ In the case of organizational defendants, the theory has been sharply criticized on the ground that profit-maximizing organizations are interested in the marginal (not the total) costs of activities relative to the marginal benefits. The total wealth of the organization generally has little to do with the expected marginal costs or benefits of actions. It has been argued that, by linking punitive damages to wealth, the law creates too much deterrence for large corporations and too little for small ones. See Robert D. Cooter, Punitive Damages for Deterrence: When and How Much?, 40 Ala L Rev 1143, 1176-77 (1989); Malcolm E. Wheeler, A Proposal for Further Common Law Development of the Use of Punitive Damages in Modern Product Liability Litigation, 40 Ala L Rev 919, 950-51 (1989); Dorsey D. Ellis, Jr., Fairness and Efficiency in the Law of Punitive Damages, $56 \mathrm{~S}$ Cal L Rev 1, 62 (1982). See also Zazú Designs v L'Oréal, SA, 979 F2d 499, 508 (7th Cir 1992); Thomas v E.J. Korvette, Inc, 329 F Supp 1163, 1170 (E D Pa 1971), revd on other grounds, 476 F2d 471 (3d Cir 1973) ("[I]t is probably safe to assume that any substantial amount of punitive damages would have deterrent effect, irrespective of the size of the corporation.").

${ }^{188} 512$ US 415, 432 (1994).

${ }^{189} \mathrm{Id}$.

${ }^{100}$ See Daniel A. Weinberg, A Brief Look at Postwar U.S. Income Inequality, Current Population Reports P60-191 (Census Bureau June 1996) (finding 22.4 percent increase in income inequality from 1968 to 1994, using the Gini index of income concentration). 
various types of misconduct. ${ }^{191}$ Referring to Alabama's procedures for setting punitive damages, Justice Powell once observed in a draft opinion that "[t]he jurors who pass sentence on tort defendants according to these procedures probably have never decided a punitive damages case before. Thus, they have no basis for de-

${ }^{191}$ See Atlas Food Systems and Services, Inc $v$ Crane National Vendors, Inc, 99 F3d 587, 594 (4th Cir 1996):

[P]olicy-related elements-e.g., the likelihood that an award will deter the defendant or others from engaging in similar conduct-are not factual questions and, therefore, are more appropriately decided by the trial judge. The judge's unique vantage point and day-to-day experience with such matters lend expertise and consistency. . . . [T] he district courts ... themselves are required frequently to impose penalties for punishment and deterrence in a wide array of circumstances, both in civil and in criminal contexts. Indeed, in criminal cases, our system gives juries virtually no input, except in capital cases, to determine the amount of penalties.

See also Gilbert $v$ St. Louis-San Francisco Railroad Co, 514 F2d 1277, 1280-81 (5th Cir 1975) (stressing that compensatory and punitive damages "are not administrable in the same fashion," and upholding remittitur of award from $\$ 225,000$ to $\$ 60,000$ because trial judge "could not justify, on principles of legal policy, a jury award in this case which so vastly exceeded an earlier award in a stronger case"); Owen, Comment, $56 \mathrm{~S} \mathrm{Cal} \mathrm{L} \mathrm{Rev}$ at 120 (cited in note 11) ("Judges have more familiarity than do juries with distinguishing 'wrong' from 'very wrong' behavior (and fixing the appropriate level of punishment therefor) upon a formal social scale ...."); Zoppo v Homestead Insurance Co, 71 Ohio St 3d 552, 644 NE2d 397, 404 (1994) (Wright, joined by Moyer, dissenting):

In order to reach a fair punishment, the decision-maker must be able to compare the wrongful conduct in this case against similar conduct in other cases. Additionally, such a broad perspective is essential in order to set a level of damages which, while fair, will adequately deter such wrongful conduct in the future. This broad perspective, which is necessary to give effect to the purposes of punitive damages, makes the judge and not the jury the appropriate decision-maker. The knowledge and experience necessary to set punitive damages effectively are unique to the judge alone.

The Zoppo majority held that a statute ordering judicial assessment of punitive damages violated the right to jury trial protected by the Ohio Constitution, id at 401 , and did not address whether, as a matter of policy, judges or juries are better suited to assess punitive damages. Compare Torres v North American Van Lines, Inc, 135 Ariz 35, 658 P2d 835, 841 (Ariz App 1982) (relying in part on trial judge's experience in personal injury lawsuits in affirming remittitur that cut punitive damages award by 75 percent). Since they took effect in 1987, the Federal Sentencing Guidelines have been interpreted by many courts to limit significantly the ability of federal judges to tailor sentences to the facts of the case. In Koon v United States, 116 S Ct 2035 (1996), however, the Supreme Court emphasized the importance of taking into account individual circumstances in sentencing under the Guidelines. Id at 2053 ("It has been uniform and constant in the federal judicial tradition for the sentencing judge to consider every convicted person as an individual and every case as a unique study in the human failings that sometimes mitigate, sometimes magnify, the crime and punishment to ensue."); see also id at 2044 (noting that Congress "[a]cknowledged the wisdom, even the necessity, of sentencing procedures that take into account individual circumstances"). Even when a court does not depart from the Guidelines range deemed to be applicable, it must exercise discretion in choosing a sentence within the range. 
termining what penalties are common in particular kinds of cases." ${ }^{\text {"192 }}$

Because judges are in a better position to impose a punishment that is in line with the punishments imposed for similar misconduct, determination of the amount of punitive damages by judges would promote the interest in treating like cases alike. ${ }^{193}$ As Professor Colleen Murphy has written, "[w]ith professional and ongoing experience in matters of public policy, the judge presumably effectuates public policy goals with greater consistency than the one-time jury."194

Whereas jury verdicts awarding punitive damages simply indicate a dollar amount, a judge could be required to state the reasons for the amount of punitive damages awarded. ${ }^{195}$ This would greatly facilitate appellate review. ${ }^{196}$ Under the current procedure, one can only speculate as to what led the jury to award punitive damages in the amount it chose. It may have relied upon an improper premise or one unsupported by the record, but the error may never be known. A requirement that a judge state the reasons for a punitive damages award would reduce the risk of undisclosed error.

Although trial judges' statements of reasons would reveal some errors that might go uncorrected on appeal if made by a jury, in general shifting to judges the responsibility to set punitive damages would have the salutary effect of reducing the role of appellate courts in setting punitive damages. ${ }^{197}$ Under the ex-

${ }^{192}$ Aetna Life Insurance Co $v$ Lavoie, 475 US 813 (1986) (draft opinion of Powell), excerpted in Lewis Powell, The 'Bizarre Results' of Punitive Damages, Wall St J A21 (Mar 8, 1995).

${ }^{193}$ Compare Markman, $116 \mathrm{~S} \mathrm{Ct}$ at 1396 (holding that judges rather than juries should construe patents in part because of "the importance of uniformity in the treatment of a given patent").

${ }^{194}$ Murphy, 61 Geo Wash L Rev at 739-40 (cited in note 134) (footnotes omitted).

${ }^{195}$ Some state appellate courts have imposed similar requirements with respect to trial court rulings on post-trial motions challenging a jury's punitive damages award as excessive. See, for example, VF Corp $v$ Wrexham Aviation Corp, 112 Md App 703, 686 A2d 647, 660 (1996), cert granted, 346 Md 28, 686 A2d 647 (1997); Hodges v S.C. Toof \& Co, 833 SW2d 896, 902 (Tenn 1992).

${ }^{196}$ See Redish, $70 \mathrm{Nw}$ U L Rev at 504 n 75 (cited in note 31) (noting that factual findings by district judges "must be made explicitly, and are subject to appellate review," but "[f] act findings by juries ... usually come in the form of an enigmatic general verdict, and are less susceptible to appellate review”). See also Charles E. Wyzanski, Jr., A Trial Judge's Freedom and Responsibility, 65 Harv L Rev 1281, 1292-93 (1952) (arguing that judges should state the reasons for sentences in criminal cases, as a safeguard against "emotion or other transient factors").

${ }^{197}$ See generally Charles Alan Wright, The Doubtful Omniscience of Appellate Courts, 41 Minn L Rev 751, 752-58 (1957). 
isting system of jury awards of punitive damages, the real determination of punitive damages often takes place on appeal. ${ }^{198}$ In countless cases, appellate courts have drastically reduced awards of punitive damages. ${ }^{199}$ Appellate courts have taken such action despite the vagueness of the criteria governing the determination of the amount of punitive damages. ${ }^{200}$

${ }^{100}$ A study of punitive damage awards returned in product liability cases between 1965 and 1990 found that roughly 55 percent were affirmed; the remainder were reversed or reduced. Michael Rustadt, Demystifying Punitive Damages in Product Liability Cases: A Survey of a Quarter Century of Trial Verdicts 31-32 (Roscoe Pound Foundation 1991).

${ }^{190}$ See, for example, Lee $v$ Edwards, 101 F3d 805, 812-13 (2d Cir 1996) (reducing jury's $\$ 200,000$ punitive damages award to $\$ 75,000$ ); Continental Trend Resources, Inc $v$ OXY USA, Inc, 101 F3d 634, 643 (10th Cir 1996), cert denied, 117 S Ct 1846 (1997) (reducing $\$ 30$ million punitive damages award to $\$ 6$ million); Vasbinder $v$ Scott, 976 F2d 118, 121-22 (2d Cir 1992) (reducing two $\$ 150,000$ punitive damages awards to $\$ 20,000$ and $\$ 30,000$ ); Mason v Texaco, Inc, 948 F2d 1546, 1561 (10th Cir 1991) (halving \$25 million punitive damages award); Rowlett $v$ Anheuser-Busch, Inc, 832 F2d 194, 206-07 (1st Cir 1987) (reducing punitive damages award from $\$ 3$ million to $\$ 300,000)$; Hollins v Powell, 773 F2d $191,194,198$ (8th Cir 1985) (reducing $\$ 500,000$ punitive damages award to $\$ 2,000$ ); Ramsey $v$ American Air Filter Co, 772 F2d 1303, 1314 (7th Cir 1985) (reducing $\$ 150,000$ punitive damages award to $\$ 20,000) ;$ Morrill $v$ Becton, Dickinson and Co, 747 F2d 1217, 1225 (8th $\mathrm{Cir} 1984$ ) (reducing $\$ 20$ million punitive damages award to $\$ 3$ million); Bell $v$ City of Milwaukee, 746 F2d 1205, 1267 (7th Cir 1984) (reducing $\$ 350,000$ punitive damages award to $\$ 50,000$ ). See generally Eric Schnapper, Judges Against Juries-Appellate Review of Federal Civil Jury Verdicts, 1989 Wis L Rev 237, 334-36. For similar state decisions, see, for example, Texaco, Inc v Pennzoil Co, 729 SW2d 768, 784, 865-66 (Tex App 1987) (reducing $\$ 3$ billion punitive damages award to $\$ 1$ billion); Faulk v Aware, Inc, 244 NYS2d 259, 266 (NY App Div 1963) (reducing two $\$ 1.25$ million punitive damages awards to $\$ 50,000$ and $\$ 100,000$ ), affd, 14 NY2d 899, 200 NE2d 778 (1964); Miller v Schnitzer, 78 Nev 301, 371 P2d 824, 829, 831 n 3 (1962) (reducing $\$ 50,000$ punitive damages award to $\$ 5,000)$.

${ }^{200}$ Judge Lee Sarokin described judicial intervention with respect to punitive damages as follows:

With the vague guidance given to juries as to the means for calculating [punitive] damages, it is difficult to justify judicial intercession on the basis that the amount of the award is invalid as a matter of law. What occurs in reality is an independent factual finding by the court simply that the penalty is too great.

Juzwin v Amtorg Trading Corp, 705 F Supp 1053, 1057 (D NJ 1989), modified on other grounds, 718 F Supp 1233 (D NJ 1989). Although it is submitted that Judge Sarokin was incorrect in using the term "factual finding" to describe the determination of the proper amount of punitive damages, he shrewdly looked behind the rhetoric of deference that often obscures a de novo judicial assessment of how severe the penalty should be. See also Miller, 371 P2d at 829 (citations omitted):

One cannot avoid thinking that the general rules offered to explain the reviewing court's decision are tailored to fit its feeling about the particular case before it. If that court does not approve the verdict it will state that the jury was motivated by passion or prejudice or that a "reasonable relationship" between the punitive and compensatory awards does not exist; or that the amount of the award is "enormous." On the other hand, the reviewing court in affirming the award may rely upon the converse of the reasons just mentioned, or upon a strong presumption in favor of the verdict as confirmed by the trial judge in refusing a new trial, or some other equally plausible statement. 
If trial judges were responsible for awarding punitive damages, there would likely be fewer enormous awards. The occasions for appellate intervention would be fewer, and appellate courts could be expected to heed more closely precedents that ostensibly limit appellate review of the amount of damages awarded. ${ }^{201}$ The result of having trial judges set punitive damages would be to reduce the frequency with which punitive damages are effectively set on a cold record by judges who heard none of the testimony presented at trial. ${ }^{202}$

Judges are also better equipped than juries to give proper weight to other sanctions that have been imposed on the defendant for the same conduct. Under the law of many states, prior fines, civil penalties, or awards of punitive damages militate in favor of a lower punitive award. ${ }^{203}$ As a practical matter, however, to require a defendant to present such proof to a jury is virtually to eliminate prior punishment as a mitigating factor. As Judge Sarokin observed with respect to evidence of prior punitive awards, "[t]o require a defendant to present such prejudicial evidence to a jury as its only alternative is to place it between Scylla and Charybdis. ${ }^{204}$ Evidence that another jury, court, or agency

Under traditional doctrine, a plaintiff may decline a remittitur and insist upon a new trial. See, for example, Vasbinder, 976 F2d at 122-23. With respect to punitive awards, some appellate decisions have departed from this principle, remanding with instructions to enter judgment in a reduced amount, rather than affording the plaintiff the option of a new trial. See, for example, Rowlett, 832 F2d at 207; Guzman, 540 F2d at 954.

${ }^{201} \mathrm{See}$, for example, Browning-Ferris Industries of Vermont, Inc $v$ Kelco Disposal, Inc, 492 US 257, 279 (1989) (holding that trial court's ruling on motion for remittitur is reviewable "under an abuse-of-discretion standard") (footnote omitted). In BMW of North America, Inc v Gore, 116 S Ct 1589, 1598-1604 (1996), the Supreme Court identified three "guideposts" that led it to conclude that an award of punitive damages was so excessive as to violate the Due Process Clause of the Fourteenth Amendment. The application of the due process limitation established in $B M W$ may not be subject to the abuse-of-discretion standard.

${ }^{222}$ On a related point, see Patrick E. Higginbotham, Juries and the Death Penalty, 41 Case W Res L Rev 1047, 1065 (1991) ("WW]e should submit the capital sentencing decision either to the judge or to the jury but not to both, and we should not permit it to be made independently by an appellate court.").

${ }^{20}$ See, for example, Green Oil Co v Hornsby, 539 S2d 218, 224 (Ala 1989). See generally Restatement (Second) of Torts \$ 908 comment e (1977) ("Another factor that may affect the amount of punitive damages is the existence of multiple claims by numerous persons affected by the wrongdoer's conduct.").

${ }^{204}$ Juzwin, 705 F Supp at 1056, modified on other grounds, 718 F Supp 1233 (D NJ 1989). See also Garnes v Fleming Landfill, Inc, $186 \mathrm{~W}$ Va 656, 413 SE2d 897, 909 (1991) (Judge rather than jury should consider prior criminal sanctions or civil awards.); Model Punitive Damages Act $\S 10(a), 14$ ULA 63 (Cum Ann Pkt Pt 1997) (Court may reduce punitive damages award if defendant was previously found liable for punitive damages under a final judgment arising from the same course of conduct, and the second award would be unfairly duplicative.). 
has sanctioned the defendant is at least as likely to lead a jury to increase its award as it is to lead it to reduce the award.

If judges set punitive damages, cases in which such damages were found to be warranted also could be resolved more quickly and with less expense. Today it is not unusual for a jury's punitive damages award to be followed by further proceedings at the trial court level that may stretch out over several months. In addition to memoranda of law supporting and opposing a remittitur, evidence not before the jury is often tendered and considered. ${ }^{205}$ If the trial judge grants a remittitur which the plaintiff accepts, the defendant may still appeal. Vesting in judges the authority to set punitive damages would significantly shorten the process.

\section{B. The Insufficient Advantages of Assessment by Juries}

The foregoing considerations strongly support shifting to judges the responsibility to decide the amount of punitive damages. They are not outweighed by the interests that might be served by leaving that responsibility with juries.

The Supreme Court has said that the purpose of jury trials in civil cases is "to assure a fair and equitable resolution of factual issues. ${ }^{2006}$ Although other interests are served by civil jury trials, the notion that a jury has a superior ability to decide issues of credibility and other factual issues is plainly one of the principal justifications for civil jury trials.

This justification provides little support for asking juries to set punitive damages. No doubt the parties may dispute some facts relevant to the amount of punitive damages. In general, however, fact resolution is likely to be less significant than the exercise of judgment as to how large an award is warranted to serve the purposes of punitive damages..$^{207}$ When the amount of punitive damages is considered, ordinarily the jury already will have found that the defendant committed a wrong that caused injury to the plaintiff, determined the extent of the plaintiff's injuries (economic and noneconomic), and determined that the defendant acted with the degree of culpability necessary to permit an award of punitive damages. Factual disputes certainly can remain, just as in a criminal case there can be factual disputes relating to sentencing. But in most cases the determination of the

\footnotetext{
${ }^{206}$ See, for example, Dunn v HOVIC, 1 F3d 1371, 1389-91 (3d Cir 1993) (en banc).

${ }^{205}$ Colgrove, 413 US at 157, citing Gasoline Products Co $v$ Champlin Co, 283 US 494, 498 (1931).

${ }^{207}$ Compare Markman, $116 \mathrm{~S} \mathrm{Ct}$ at 1395.
} 
amount of punitive damages is driven not by factual questions but by a subjective judgment as to the amount that will serve the purposes of punitive damages (typically, punishing the defendant and deterring both the defendant and others from similar conduct in the future $\left.{ }^{208}\right)$. As Professor Ellis has observed, determining the amount of punitive damages "does not require answering a "what happened' question. Rather, it embodies the question, 'what ought to happen' to the defendant."

Jury determination of the amount of punitive damages also might be deemed preferable because a jury's verdict reflects the judgment of all the jurors, whereas a judge's determination is the judgment of one man or woman..$^{210}$

A nineteenth century Supreme Court decision, Railroad Co $v$ Stout, ${ }^{211}$ though not involving punitive damages, endorsed the wisdom-of-many justification for jury trials. Stout, a six-year old, seriously injured a foot while playing on an unguarded railroad turntable located near a public road. The facts were not in dispute. The jury returned a verdict of $\$ 7,500$ against the railroad.

${ }^{208}$ See Boston, Punitive Damages at $\$ \S ~ 2: 6-2: 7$ (cited in note 185).

${ }^{200}$ Ellis, 40 Ala L Rev at 1004 (cited in note 11). See Murphy, 61 Geo Wash L Rev at 802 (cited in note 134) ("Even if some factors are questions of pure fact-for example, the profitability of defendant's misconduct-the calculation of punitive damages cannot be said to be fact-dependent . ....”) (footnote omitted). See also Gasperini, 116 S Ct at 2235 (Scalia dissenting) ('[T]he level of punitive damages is not really a 'fact' 'tried' by the jury."). The distinctive character of punitive damages determinations was aptly described by a Justice of the Supreme Court of Oregon:

In the trial of a criminal case the jury finds the facts and two days thereafter the judge imposes sentence. I have never heard it suggested that the judge in so doing is finding the facts. He is exercising a purely discretionary power to impose punishment, a power which is limited by the statutory maximum sentence which may be imposed. In the same manner the jury, in determining whether to assess punitive damages and in what amount, exercises a purely discretionary power based upon the facts which it has already found, a power which resembles that of the trial judge, except for the fact that his discretion is limited by statute whereas theirs is without limit unless the court imposes one.

Van Lom v Schneiderman, 17 Or 89, 210 P2d 461, 475-76 (1949) (Brand concurring in part and dissenting in part). See also Prince v Peterson, 538 P2d 1325, 1329 (Utah 1975) (noting that in awarding punitive damages "the jury exercises a quasi-judicial function") (footnote omitted).

That setting punitive damages may involve some factual questions does not suggest that judges are incapable of setting such damages. "Courts pass upon a vast number of questions of fact. . . [ [T] here is not, and never was, any such thing in jury trials as an allotment of all questions of fact to the jury. The jury simply decides some questions of fact." James Thayer, A Preliminary Treatise on Evidence at the Common Law 185 (Kelley 1969) (originally published 1898).

${ }^{210}$ See Charles Jared Knight, Note, State-Law Punitive Damage Schemes and the Seventh Amendment Right to Jury Trial in the Federal Courts, 14 Rev Litig 657, 683 (1995).

${ }^{211} 84$ US (17 Wall) 657, 663-64 (1873). 
In the Supreme Court the railroad argued that, since the facts were undisputed, the issue of its negligence should have been decided by the judge as a matter of law. ${ }^{212}$ The Court rejected the argument, explaining that in most cases of alleged negligence,

[u]pon the facts proven in such cases, it is a matter of judgment and discretion, of sound inference, what is the deduction to be drawn from the undisputed facts. . . Twelve men of the average of the community, comprising men of education and men of little education, men of learning and men whose learning consists only in what they have themselves seen and heard, the merchant, the mechanic, the farmer, the laborer; these sit together, consult, apply their separate experience of the affairs of life to the facts proven, and draw a unanimous conclusion. This average judgment thus given it is the great effort of the law to obtain. It is assumed that twelve men know more of the common affairs of life than does one man, that they can draw wiser and safer conclusions from admitted facts thus occurring than can a single judge. ${ }^{213}$

Today civil juries in federal court generally have only six or eight members rather than twelve. More importantly, however, the nature of the decision involved in awarding punitive damages suggests that the wisdom of a judge is preferable in this instance to the collective wisdom of a jury. Choosing an amount of punitive damages differs fundamentally from the determination of whether a party was negligent and from other applications of law to fact that are submitted to the jury even when the facts are undisputed (if reasonable persons could disagree about the outcome). The determination of whether a party was negligent, though certainly subjective in part, is guided by consideration of what a reasonable person in the defendant's shoes would have done. For most other issues decided by a jury there are similar objective criteria. The choice of the amount of punitive damages is not guided in any comparable way that makes the jury's knowledge of "the common affairs of life ${ }^{\text {"214 }}$ particularly useful.

${ }^{212}$ Id at 659.

${ }^{213}$ Id at 663-64. See Bailey v Central Vermont Railway, Inc, 319 US 350, 353 (1943) ("[T] $]$ he fact that fair-minded men might reach different conclusions, emphasize[s] the appropriateness of leaving the question to the jury."); Orkin Exterminating Co $v$ Truly Nolen, Inc, 117 S2d 419, 423 (Fla Dist Ct App 1960).

${ }^{214}$ Stout, 84 US at 664. 
Another justification often advanced for jury trials in civil cases is the risk of judicial bias. This justification was advanced by the Anti-Federalists, ${ }^{215}$ who in urging a jury-trial guarantee for civil cases quoted the following statement by Blackstone:

The impartial administration of justice, which secures both our persons and our properties, is the great end of civil society. But if that be entirely entrusted to the magistracy, a select body of men, and those generally selected by the prince or such as enjoy the highest offices in the state, their decisions, in spite of their own natural integrity, will have frequently an involuntary bias towards those of their own rank and dignity; it is not to be expected from human nature that the few should be always attentive to the interests and good of the many. ${ }^{216}$

In Pennsylvania, the Anti-Federalists cited an outrageous search by a constable that had resulted in an award of damages by a jury, and predicted that a "lordly court of justice" sitting without a jury would be "ready to protect the officers of government against the weak and helpless citizens.

It cannot be denied that in some instances bias could infect determinations of punitive damages by federal judges. But this possibility does not provide a good reason for continuing to leave those determinations in the hands of juries in all cases. First, a check against the operation of judicial bias would be provided by the fact that the amount of punitive damages would not be decided by the judge unless the jury first determined that the defendant was liable for punitive damages. Second, the strong tradition of independence and professionalism that has developed in the federal judiciary reduces the risk of judicial bias. ${ }^{218}$ Third, the

\footnotetext{
${ }^{215}$ See Centinel, in Herbert J. Storing, ed, 2 The Complete Anti-Federalist 143, 149 (Chicago 1981).

${ }^{216}$ Blackstone, 3 Commentaries on the Laws of England at 379 (cited in note 142) (emphasis added).

${ }^{217}$ Pennsylvania Packet (Oct 23, 1787), in John Bach McMaster and Frederick D. Stone, eds, Pennsylvania and the Federal Constitution 154 (Hist Soc Penn 1888). The author went on to say that if federal officers "commit similar or greater indignities, in such cases a trial by jury would be our safest resource, heavy damages would at once punish the offender and deter others from committing the same." Id. See also Essays by $a$ Farmer, Maryland Gaz (Feb 15, 1788), in Storing, ed, 5 The Complete Anti-Federalist at 14.

${ }^{218}$ See Redish, $70 \mathrm{Nw}$ U L Rev at $504 \mathrm{n} 75$ (cited in note 31) (" $[\mathrm{B}]$ ecause of the generally careful selection process, federal judges are likely to be highly experienced, intelligent individuals steeped in traditions of the law. Thus, it is probable that at least in most cases judges will be better able to control their prejudices than will jurors.").
} 
risk of judicial bias could be further reduced by having juries continue to set punitive damages in cases involving alleged abuses of government power, in which a judge's status as part of the government might be a source of bias. ${ }^{219}$

It has been suggested that juries should set punitive damages because juries better represent the values of the community. ${ }^{220}$ One of the functions of the jury system undoubtedly is to permit the ideals and beliefs of ordinary citizens to influence the administration of the law. ${ }^{221}$ This function of jury trials provides little justification, however, for having juries set punitive damages.

Any allocation of decisionmaking authority to judges could be said to reduce the influence that community values exert through jury verdicts, but the law entrusts many important decisions to

${ }^{219}$ Punitive damages were first recognized by English courts in cases in which official power had been abused and juries returned awards far in excess of the plaintiffs' actual loss. See Wilkes, 98 Eng Rep at 498-99; Huckle, 95 Eng Rep at 768-69.

If further protection against judicial bias in the award of punitive damages were deemed important, a proposal made years ago by the late Judge Edward J. Devitt could be adopted in part. Although Judge Devitt advocated amending the Constitution to eliminate the right to a jury trial in civil cases, he also suggested that, short of such an amendment, the statute permitting a party to seek disqualification of a judge based on bias or prejudice, 28 USC § 144, be amended "to provide a peremptory challenge when counsel questioned the fairness of the assigned judge," so that more litigants would be willing to waive a jury trial. Edward J. Devitt, Federal Civil Jury Trials Should Be Abolished, 60 ABA J 570,572 (1974). Such a peremptory challenge could be provided in cases in which punitive damages are sought. In 1997, bills were introduced in Congress that would have given each side in a case in federal court one opportunity to request reassignment of the case to a different judge. HR 520, 105th Cong, 1st Sess $\$ 2$ (1997) (civil and criminal cases); HR 1252,105 th Cong, 1st Sess $\$ 6$ (1997) (civil cases only).

The Anti-Federalists also touted jury trials in civil cases as a safeguard against corruption, on the ground that it is more difficult to bribe jurors than judges because "it is not, generally, known till the hour the cause comes on for trial, what persons are to form the jury." Federal Farmer 15 (Jan 18, 1788), in Storing, ed, 2 The Complete Anti-Federalist at 321 (cited in note 215). See also Federalist 83 (Hamilton), in Rossiter, ed, The Federalist Papers at 500 (cited in note 25) ("there is always more time and better opportunity to tamper with a standing body of magistrates than with a jury summoned for the occasion"). The extended length of many modern jury trials would seem to make the lack of pretrial knowledge of the jurors' identity a poor safeguard against bribery. Moreover, bribery of judges has been an extremely rare occurrence in the federal judicial system.

${ }^{200}$ See Alan Howard Scheiner, Note, Judicial Assessment of Punitive Damages, the Seventh Amendment, and the Politics of Jury Power, 91 Colum L Rev 142, 188-89, 196-97 (1991). See also Knecht $v$ Radiac Abrasives, Inc, 219 Ill App 3d 379, 579 NE2d 1248, 1251 (1991) ("The jury, with its unique ability to articulate community values, should decide whether punitive damages should be imposed.").

${ }^{221}$ See, for example, Markman, $116 \mathrm{~S}$ Ct at 1395 (referring to jury's ability "to reflect community standards"); Oliver Wendell Holmes, Law in Science and Science in Law, 12 Harv L Rev 443, 459-60 (1899) (citing the jury's role in keeping the law in accord with community values as a function served by entrusting determinations of negligence to the jury). 
judges, such as sentencing, imposition of civil penalties, and grant or denial of injunctions and declaratory judgments. Moreover, as Judge Kozinski has noted recently, whereas "[l]egislators are popularly elected and represent a variety of geographic and other interests ... [,] any group of six or 12 individuals may have views wholly unrepresentative of the community at large. ${ }^{.222}$ The reduction in the size of civil juries in federal cases makes particularly suspect the notion that a jury is a reliable barometer of community values. When the issue of the proper amount of punitive damages arises, the defendant already has been found, ordinarily by a jury, to have engaged in culpable conduct. Particularly given the other considerations suggesting that judges are better equipped than jurors to set punitive damages, it seems better to bypass this one opportunity for the expression of community values through juries, and to rely on judges to be guided by established norms of which they will be well aware (such as the need to respect persons and property).

Jury trials also afford citizens an opportunity to participate in government. As one Anti-Federalist tract argued,

The trial by jury in the judicial department, and the collection of the people by their representatives in the legislature, are those fortunate inventions which have procured for them, in this country, their true proportion of influence, and the wisest and most fit means of protecting themselves in the community. Their situation, as jurors and representatives, enables them to acquire information and knowledge in the affairs and government of the society; and to come forward, in turn, as the centinels and guardians of each other. ${ }^{223}$

The participatory function of jury trials is important, but it does not deserve great weight with respect to the allocation of power under consideration here. To assign judges the power to set punitive damages would merely confer on judges the power to decide one aspect (the determination of amount) of one remedy (punitive damages). It would not substantially reduce the opportunity for public participation in government through jury service. ${ }^{224}$

${ }^{222}$ Kozinski, Ind Law at 12 (cited in note 11). See also Martin A. Kotler, Reappraising the Jury's Role as Finder of Fact, 20 Ga L Rev 123, 171-72 (1985) (arguing that juries are not "representative of the same group of persons as the legislature").

${ }^{223}$ Federal Farmer 4 (Oct 12, 1787), in Storing, ed, 2 The Complete Anti-Federalist at 249-50 (cited in note 215). See Scheiner, Note, 91 Colum L Rev at 195 (cited in note 220) ("[J]ury participation in the assessment of damages is a living form of direct democracy.").

${ }^{22}$ See, for example, Comment, Criminal Safeguards and the Punitive Damages Defendant, 34 U Chi L Rev 408, 421 (1967) ("[D]emocracy will not falter if a jury does not par- 
It has been argued that juries should set punitive damages because "the right to trial by jury lends credence to the decisions of our courts and engenders public confidence in the legal system," and "any efforts on behalf of the judiciary to substantially detract from that right . . . will weaken the confidence of the people in the courts. ${ }^{3225}$ Although it is true that jury trials traditionally have been thought to be important in maintaining confidence in the legal system, the reality is that awards of punitive damages returned by juries are set aside altogether or reduced in an extraordinarily high percentage of cases. ${ }^{226}$ If anything, taking determinations of the amount of punitive damages away from juries might well increase public confidence in the judicial system, because it would end a type of jury verdict that is partially or entirely overturned with exceptional frequency-perhaps more often than any other type of jury verdict. Moreover, the suggested change would merely take from the jury one part of one issue; juries would still determine liability for compensatory damages, amount of compensatory damages, and liability for punitive damages.

\section{Summary}

In cases brought in federal court, the responsibility to set punitive damages should rest with the trial judge (except in cases involving alleged abuses of governmental power). ${ }^{227}$ The jury could be asked to return an advisory verdict on the amount of punitive damages; Federal Rule of Civil Procedure 39(c) expressly authorizes the use of advisory juries. ${ }^{28}$ Ultimately, however, the power to determine the proper amount of punitive damages should rest with the trial judge, subject to appellate review. ${ }^{229}$

\section{IMPLEMENTING THE CHANGE}

It might be questioned whether federal courts, even if disposed to do so, can implement the change recommended here on their own, or whether they must await a statute or an amend-

ticipate in every proceeding.").

${ }^{225} \mathrm{Knight}$, Note, 14 Rev Litig at 683-84 (cited in note 210).

${ }^{205}$ See notes 198-99.

${ }^{227}$ See text accompanying notes 218-20.

${ }^{223}$ See generally Note, Practice and Potential of the Advisory Jury, 100 Harv L Rev 1363, 1364-67 (1987).

${ }^{220}$ Where not precluded by a jury-trial guarantee of the applicable state constitution, the proposal advanced here may also merit consideration in state court systems with a strong tradition of a professional and independent judiciary. 
ment to the Federal Rules of Civil Procedure. No statute or amendment to the Rules is necessary.

In Colgrove, ${ }^{230}$ the Supreme Court upheld a local federal court rule providing that juries in civil cases would consist of six persons. Not only was there no statute or Federal Rule of Civil Procedure authorizing six-person juries, but at that time Rule 48 provided that "[t]he parties may stipulate that the jury shall consist of any number less than twelve ${ }^{\text {2231 }}$ and thus contemplated a twelve-person jury absent such a stipulation. The Court held that Rule 48 was no obstacle to the local rule, because it was drafted in light of the assumption, held in Colgrove to be incorrect, that a trial by jury meant a trial by a jury of twelve persons. ${ }^{232}$ Since no provision of the Federal Rules of Civil Procedure even reflects the assumption that juries are to set punitive damages, under Colgrove federal courts are free to adopt local rules providing for judicial determination of the amount of punitive damages. Even absent a local rule, an individual judge presumably may consider providing in a pretrial order that the amount of punitive damages will be set by the court if liability for such damages is found by the jury. ${ }^{233}$

\section{CONCLUSION}

An award of punitive damages is a "windfall" to the plaintiff. ${ }^{234}$ As one court put it, the plaintiff "is the fortuitous beneficiary of such an award simply because there is no one else to receive it. ${ }^{.235}$ It would be anomalous if the fortuitous beneficiary of a windfall had a constitutional right to choose the decisionmaker who determines the amount of the windfall. It would also be anomalous if defendants in civil cases had a constitutional right

${ }^{200} 413$ US at 163-64.

${ }^{231}$ See id at 185 (Marshall dissenting).

${ }^{22}$ See id at 163-64. Rule 48 was amended in 1991 to direct trial courts to seat juries of not fewer than six and not more than twelve members. 28 USCA Rule 48 (1992).

${ }^{23}$ In diversity cases, a state practice of asking juries to fix punitive damages need not be followed unless it is bound up with state-created rights and obligations. The allocation of power between judges and juries is ordinarily a matter of federal procedural law, not an issue on which state law must be followed under the Erie doctrine. See Byrd v Blue Ridge Rural Electric Cooperative, 356 US 525, 535-40 (1958); Meyers $v$ Selznick Co, 373 F2d 218, 222 n 1 (2d Cir 1966). Compare Tingley Systems, Inc v Norse Systems, Inc, 49 F3d 93, 96 (2d Cir 1994) (provision of Connecticut Unfair Trade Practices Act assigning determination of punitive damages to judge would have justified a new trial in case brought in federal court, where the district court has submitted the issue of punitive damages to the jury).

${ }^{234}$ City of Newport $v$ Fact Concerts, Inc, 453 US 247, 267 (1981).

${ }^{235}$ Katko v Briney, 183 NW2d 657, 662 (Iowa 1971). 
to have punitive damages set by a jury, whereas in criminal cases judges determine sentences of imprisonment (and in some cases even death ${ }^{236}$ ). Because the Seventh Amendment need not and should not be interpreted to entitle either plaintiffs or defendants to have a jury fix punitive damages, judicial assessment of punitive damages merits much more consideration than it has received, as an alternative to caps and other reforms designed to curb excessive awards. 


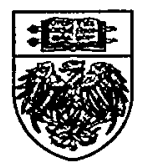

